\title{
Haves de indagación para articular la historia de la educación visual en la ciudad de Neiva
}

Jaime Ruiz Solórzano

jairuso@usco.edu.co Docente Universidad Surcolombiana Grupo de investigación ALTERARTE

I siguiente texto constituye una entrada a la historia de la educación visual, acaecida en la ciudad de Neiva entre 1884 y principios del año 2004; es decir, desde la puesta en funcionamiento de la Escuela de Artes y Oficios hasta la expansión de lo que en su tiempo se llamó "la educación visual no formal".

Para ello el escrito contempla los siguientes apartados 1. La educación visual a través del sistema educativo y los textos escolares, con dos apartados: uno sobre la educación artística y estética; otro inherente a los fotograbados, grabados e ilustraciones de los textos escolares. 2. La institucionalización de la educación visual que abarca, primero, la "Sección de Extensión Cultural del Departamento" y la creación del Instituto Técnico Universitario Surcolombiano ITUSCO; segundo, la "Escuela de Bellas Artes"; tercero, la Licenciatura de Artes Visuales de la Universidad Surcolombiana y "la educación visual no formal".
Se debe aclarar que en esta investigación se empleó la metodología de la investigación histórica. Desde esta perspectiva, su título alude a la necesidad de completar la investigación con otros documentos, fuentes secundarias e información oral con el fin de constituir una narrativa explicativa más cercana a nuestra contemporaneidad.

1. la educación visual a través del sistema educativo y los textos escolares

\subsection{La educación artística y estética}

Como precedente de la institucionalización de la educación artística, podemos mencionar que la ciudad contó con la Escuela de Artes y Oficios $^{4}$, iniciada desde finales del siglo XIX; aclarando que tenia más de oficios que de arte. El sentido que se le atribuye a esta Escuela es la adopción de programas relacionados con la manufactura artesanal de diversos productos. Lo cual, de manera ideal, se encaminaría a

\footnotetext{
${ }^{4}$ Posiblemente su modelo fue adaptado del movimiento artistico Arts and Crafs, que surgió en Inglaterra en 1880 basada en la teoría del arte de John Ruskin. Esta escuela se desarrolió en el Reino Unido y en los Estados Unidos entre finales del Siglo XIX y los comienzos del Siglo XX. Alcanzó su apogeo entre 1880 y 1900, cuando los artistas seguidores de William Morris quisieron revivir las formas de hacer medievales, basadas en la organización y producción artesanal altamente cualificadas.
} 
articular el sustrato que posteriormente se convertiría en verdaderas industrias.

Al respecto, Jairo Ramírez Bahamón explica la manera como el Diputado Antonio Solano, presentó una serie de propuestas para la reapertura del Colegio Santa Librada en el año de 1884: "por ejemplo, la enseñanza de la sastrería, pues para ello bastaba con traer a un sastre de la ciudad, que no necesitaba sino unas tijeras y una tiza para enseñar a los alumnos a cortar y coser un vestido"s. Igual procedimiento sugeria para la enseñanza de tejidos de sombreros de nacuma, de cobijas y de alfombras. Además estas enseñanzas estarian apoyadas por las empresas de la ciudad ${ }^{6}$

Efectivamente, el $1^{\circ}$ de junio de 1884 el Colegio Santa Librada reinició sus labores académicas como escuela secundaria, "de mineralogía y agrimensura, con la perspectiva de crear una escuela práctica de artes"7, "en el próximo año, se darian enseñanzas prácticas de herrería, carpintería y zapatería, en talleres dependientes del colegio, para lo cual se contaba ya con el ofrecimiento de talleres por parte del señor Domingo Liévano, entonces presidente de la Compañia Fabril del Huila"в .

Podemos afirmar que en Colombia la educación artística hacía parte de la política educativa "que el presidente Santander introdujo en la enseñanza pública, tal vez como consecuencia de sus experiencias en Europa...En octubre 8 de 1836 Santander reforma la "organización del colegio"s ; con lo cual, las estudiantes de las instituciones educativas a la par de "costura y bordado" aprendían "dibujo de flores y enseñanza musical vocal e instrumental"...El 4 de julio de 1838 el General añade "la copia de láminas famosas, (que) serán temas únicos no sólo en la enseñanza femenina, sino también en la actividad artística de los aficionados"10. Probablemente este aprendizaje se realizaba con docentes sin formación artística, pero con la mejor buena voluntad; como desafortunadamente ocurre aún hoy en muchas instituciones del sector educativo.

Al respecto dice Barney-Cabrera "'Las raíces de ese gusto, en consecuencia, y de los amanerados cuadritos con que en lo sucesivo se nutrirá la producción artística, se originan en aquella enseñanza que, a falta de academias, fue la única que tuvo la juventud colombiana en relación con el arte durante los primeros sesenta años del siglo (XIX)"11. Con ello se deduce el arraigamiento que todavía poseen estas producciones y consumos en las sensibilidades de la población neivana.

Asi mismo, en 1903 el sistema educativo ordena la enseñanza del "dibujo lineal" en el Plan de restudios para las "Escuelas Primarias de las áreas urbanas", al tiempo que excluyó de esta formación a las "Escuelas Rurales"12. Esta área de aprendizaje se decidió así: "Primer año: Conocimiento y clasificación de líneas, y aplicación de esto a dibujos variados,

${ }^{5}$ RAMÍREZ BAHAMÓN, Jairo. Historia social de una utopia escolar. La educación en el Estado Soberano del Tolima 1861-1886. Neiva. Ed.

Universidad Surcolombiana-Instituto Huilense de Cultura-Academia Huilense de Historia, 1998, pág. 303

${ }^{6}$ Ibidem.

${ }^{7}$ Ibidem, pag. 268.

${ }^{8}$ Ibidem, pág. 304

9 BARNEY-CABRERA, Eugenio. La actividad artística en el siglo XIX en JARAMILLO URIBE, Jaime (Director científico). Nueva historia de

Colombia, República siglo XIX Tomo 2. Bogotá, Ed. Planeta Colombiana, 2001, pág. 302.

${ }^{10}$ lbidem.

${ }^{11}$ Ibidem

${ }^{12}$ Ley 39 de Octubre 26 de 1903 y Decreto Reglamentario N 491 de Junio 3 de 1904, Articulo 69. 
formados con líneas rectas. Segundo año: Repaso de lo anterior y además conocimiento y clasificación de los ángulos, de los triángulos y de los cuadriláteros. Dibujos en el tablero y en la pizarra de objetos y figuras formales con líneas rectas. Tercer año: Polígonos en general, su clasificación y construcción de los más importantes. Círculo y circunferencia, líneas y secciones del círculo. Dibujos sencillos en papel, en los cuales entren rectas y curvas. Cuarto año: Problemas sobre la construcción de figuras geométricas, conocimientos y construcciones de las principales líneas curvas. Dibujos en papel, en los cuales entren rectas y curvas a la vez. Quinto año: Conocimiento de la escala al $1 / 10$, al $1 / 100$ y al $1 / 1000$ (escalas de yardas $y$ de pies, reducción de escalas). Dibujo de planos fáciles, haciendo uso de la regla y el compás, dibujos de muebles, de máquinas, etc. Sexto año: Dibujo geométrico y de planos fáciles, aplicando la regla y el compás; dibujo de muebles, máquinas, planos de casas, de terrenos cortos, geográficos, etc." ${ }^{13}$. Como podemos ver, los contenidos que se impartían de manera gradual, retomando contenidos de años anteriores y con un enfoque esencialmente pragmático; en otras palabras, no facilitaban el desarrollo de las capacidades expresivas.

El aseguramiento de la enseñanza del dibujo fue establecido por la Asamblea Departamental mediante la Ordenanza Número 5 del 15 de Marzo de 1911, mediante la cual se estableció la Escuela Normal de Institutoras ${ }^{14}$. Este programa que funcionó en Neiva, complementaba la educación artística de las educadoras con la formación en música y canto. A continuación, la misma duma organizó la
Educación Pública a través de la Ordenanza Número 22 del 21 de Abril de 1911. Este documento especifica que en la educación primaria se impartía "geometría aplicada al dibujo, canto, urbanidad...y trabajo manual para ambos sexos"; mientras tanto, para la educación secundaria se ofrecía "artes y oficios"15.

Se hace evidente que el sistema educativo departamental terminó fusionando las dos orientaciones de la educación artística, en las Escuelas Primarias de las áreas urbanas, con el Decreto Número 45 del 26 de Septiembre de $1916^{16}$. Para el primer año se impartía "Dibujo y trabajo manual. 3 clases de 15 minutos. Conocimiento y clasificación de las líneas con ejercicios instructivos, para determinar su posición, dirección y proporciones. Formar figuras de líneas rectas con botones o palitos y copiarlas en la pizarra o en papel. Construcción de objetos de papel, forrar libros, hacer cuadernos"17.

Igualmente, para orientar las "nociones científicas" se enfatizaba en el conocimiento de las formas, basado en cuerpos geométricos y tipos de líneas; los tamaños por comparación; y los colores, clasificados como "simples y compuestos", los nombres de los colores, la "explicación de este fenómeno", su significado en la "historia sagrada y en la naturaleza" y el uso de los colores. Además, se motivaba el conocimiento de la forma, el tamaño y los colores mediante el desarrollo de todos los sentidos corporales ${ }^{18}$.

\footnotetext{
${ }^{13}$ Ibidem.

${ }^{14}$ GACETA OFICIAL. Ordenanzas de la Asamblea del Huila 1911-1914. Neiva. Ed. Imprenta Oficial, Marzo 24 de 1911, pág. 000045.

${ }^{15}$ GOBERNACION DEL HUILA. Ordenanzas 1911-1914. Neiva. Fondo Academia Huilense de Historia, Abril 21 de 1911 , pág. 000119 y 000122

${ }^{16}$ GACETA DEL HUILA. Número 369. Neiva Ed Imprenta del Departamento. Octubre 5 de 1916, pág. 548-550.

${ }^{17} \mathrm{lbidem}$, pág. 548.

${ }^{18}$ Ibidem.
} 


\section{PAIDEIASuscolombiana 17}

En el segundo año, en la misma asignatura y asignación de tiempo, se estudiaban "ángulos triángulos y polígonos. Dimensiones, formas y colores de las superficies y figuras planas. Plegado de papeles para dar ideas de las figuras y dibujo de ellas, así como de las que inventen los niños combinando tablitas o cartones de distintas formas. Dividir a pulso y ojo linea rectas y espacios en partes iguales, calcular distancias y comprobarlo después. Construcción de objetos sencillos pero útiles a elección de los niños para el desarrollo de la facultad de inventar como esteras, lazos, papeleras, tapa tiestos, etc." ${ }^{19}$. En el desarrollo de las "nociones científicas", se continuaban las pautas del anterior curso, añadiendo las "propiedades generales de los cuerpos" y las calidades texturales.

En el tercer año se debía orientar en el dibujo y trabajo manual: "La circunferencia y sus principales líneas, división de ellas en grados y minutos. Observación de las formas y dimensiones de los cuerpos sólidos. Construcción de éstos por los niños en greda, pasta, yeso o madera y de las pesas y medidas más usadas. Dibujo de lo que construyan, máquinas, edificios, planos y de los productos naturales que estudien evitando lo que sea copia servil o mecánica. Construcción de objetos útiles más difíciles, como jaulas, cestos para matas, repisas u obras en pequeños de arquitectura, y en fin todo lo que tienda en cada año a educar la vista, el pulso, la imaginación, el entendimiento, el gusto estético y en lo posible todas las buenas inclinaciones del niño" 20.

Sin embargo, "En las Escuelas de niñas se sustituirán lo que no sea propio de ellas con dibujos de flores, letras y adornos para bordados, fabricación de flores artificiales y preparación de materiales, alfombras, marcado de ropa, aplanchado, etc."21. Con un claro prejuicio de minusvalía de las niñas y determinación de los roles tradicionales de las mujeres. De otra parte, en este año, las nociones de ciencia se orientaban al estudio de los seres de la naturaleza, las producciones de objetos y generalidades del hombre.

La Educación Secundaria continuó con el sistema de formación artesanal, hasta que en 1918 se introdujo la enseñanza del dibujo como "resumen de lo enseñado en la escuela elemental, con las siguientes ampliaciones: ángulos adyacentes y opuestos, medición del ángulo, valor y equivalencia de los triángulos y polígonos, dibujo natural de instrumentos y de máquinas sencillas aplicables a las artes o industrias manuales y de objetos de uso doméstico"22. Se intuye que la categoría de "dibujo natural" y sus representaciones, pudo facilitar un acercamiento a representaciones del bodegón.

En relación a las practicas reales de los docentes, podemos conocerlas por medio de los informes que rendian ante las autoridades educativas: "para el dibujo y trabajo manual; los educandos por medio de su trabajo han coleccionado lo siguiente: escaleritas, trapecios, telares, macanas, reglas, ángulos, triángulos, cuadrados, polígonos, cuadriláteros, todo de guache, guadua y madera; de alambre, medios circulos, circunferencias; de hueso, agujas, lanzas, tenedores etc.; de papel, cometas, abanicos y otras cosas; de bejuco,

${ }^{16}$ Ificidem.

${ }^{19}$ Ibidem, pág. 549.

"Ibidem, pág. 550.

"Ibidem.

GACETA DEL HUila. Decreto Número 25. Neiva, Ed. Imprenta del Departamento, Mayo 22 de 1918, pág. 1334. 
canastos; de lana y algodón, cobertores, cortes para pantalones, sudaderos, toallas, pabellones, gorros, hilo, fajas; de crochet, puntas para sábanas, cojines, pañitos caladitos; de cabuya, lazos, sinchas (sic), mochilas, cabezales, chiles para pezcar (sic); de crin, cerdas, sinchas (sic); de paja, capas, sudaderos; vestidos confeccionados y dibujos de papel"23.

Como se puede observar en tales informes de actividades académicas, los docentes no pudieron entender, tal vez por falta de conocimiento o voluntad, y las autoridades fueron incapaces de hacer aplicar los avances establecidos para la educación artística en 1916, de manera similar a como acontece hoy en día. De aquí, podemos comprender que la producción artesanal se haya extendido a la ciudadania neivana, postergándose las bondades que ofrecía la educación artística para el desarrollo de la sensorialidad, la sensibilidad, la creatividad y el conocimiento de la realidad, que demandaban las directrices gubernamentales.

Un indicativo del reconocimiento social que tuvo este tipo de manufacturas, se puede leer en el comunicado de las "Segundas Ferias de Neiva", celebradas del 24 al 28 de noviembre de 1919, con una "exposición de animales y de industrias fabriles". En este evento la Junta de Ferias otorgó tres medallas de oro por el mejoramiento de razas animales y una "al señor don José María Bustamante, como premio a la labor industrial en la construcción del reloj para la torre de la iglesia de Aipe". También merecieron "especial mención, los artículos presentados y fabricados por los señores Tavera \& Calderón, como las hamacas, cobertores etc.; Liscano Hermanos, por sus pieles curtidas y obras de talabartería; la estera de junco presentada por la señora Bertilda Carrera de Solano; y el espejo construido por la señorita Natalia Gutiérrez; obras que demuestran el plausible adelanto industrial en esta ciudad y que serán factor notable en el desarrollo comercial de ella"24.

Años más tarde, cuando Ricardo Olano visitó Neiva en 1935, se maravillaba por la existencia de un "museo de trabajos manuales de los niños de las escuelas" que existía en la oficina del Director de Educación, al interior del "Palacio de las 56 ventanas". Al respecto escribe: "Yo había conocido en Nueva York, algo parecido. Guardada las distancias y teniendo en cuenta las facilidades del medio, me parece el de Neiva más interesante. Hay aeroplanos, automóviles, autobuses, molinos para casa, ruedas pelton, casas, muebles, flores y frutas artificiales, obras de encuadernación, obras de latonería, vasijas de barro pintadas, vestidos, varias obras de fibra vegetal como sombreros, canastas, pantuflas, cortinas, cinturones, sacos de mano, morrales, cojines, hamacas, alpargatas, etc. etc". Tal vez, los objetos exhibidos correspondian a actividades familiares o próximos el entorno citadino de los estudiantes.

El impacto de este tipo de educación en Neiva se confirma con el censo de 1938, cuando al registrar las "industrias de transformación" se identificaron en 26 categorías, de las cuales 10 corresponden a actividades creativas que se desarrollaban en la ciudad: 1. Imprentas y artes gráficas. 2. Industrias de curtidos de cuero, (incluye tenerías y curtiembres). 3. Zapaterias, talabarterías y otras industrias del cuero. 4. Joyerías, platerías y refinerías de metales preciosos. 5. Preparación de maderas,

${ }^{23}$ GACETA DEL HUILA. Informe de la profesora Dolores Ardila R., Santa Librada, Septiembre 25 de 1919. Neiva, Ed. Imprenta del Departamento, 1920 , pág. 8.

${ }^{24}$ GACETA DEL HUILA. Neiva, Ed. Imprenta del Departamento, Enero 10 de 1920, pág. 21-24. 
carpinterías, ebanisterías. 6. Industrias de fibras animales y vegetales. 7. Fábricas de barro cocido. 8. Industrias textiles. 9. Sastrerías, modisterias, sombrererias. 10. Fabricación de sombreros de fieltro y de paja ${ }^{25}$.

Un avance importante para la educación artística y estética se originó con la iniciativa de fomentar las artes, ordenar la arquitectura y controlar el urbanismo en 1925, cuando la Asamblea Departamental ordenó crear "una junta compuesta de tres miembros especialistas en bellas artes ${ }^{26 "}$, adscritos a la Dirección de Instrucción Pública, con las siguientes funciones:

$1^{\circ}$ Fomentar en el Departamento el desarrollo del sentimiento de lo bello por medio del estudio del dibujo y de la estética;

$2^{\circ}$ Inspeccionar la construcción de edificios y monumentos públicos para que su estructura y ornamentación se ajusten a los principios del arte;

$3^{\circ}$ Propender a que la reconstrucción, refección o adaptación a otros usos de edificios o monumentos públicos se ajusten de igual modo a los mismos principios;

$4^{\circ}$ Hacer que se sujeten a los indicados principios las construcciones o reformas de avenidas, calles, plaza, parques y jardines públicos;

$5^{\circ}$ Visitar de acuerdo con los reglamentos los edificios, monumentos, bibliotecas, paseos, parques y jardines públicos y hacer a las entidades correspondientes las indicaciones necesarias para su mejoramiento, conservación y ornato, de conformidad con las reglas del buen gusto;

$6^{\circ}$ Fomentar la enseñanza del dibujo del natural en todas las escuelas y colegios del

\section{Departamento"27}

Como intención de impulsar "la educación del sentimiento estético" en 1939, se propuso embellecer las escuelas: "Si pretendemos hacer una reforma inteligente, principiemos por embellecer la escuela; hagamos de ésta un lugar amable y grato en donde los niños se sientan mejor que en cualquier otro sitio...la educación del sentimiento estético forma parte de la educación moral porque ella prepara el espíritu para contemplar el reflejo de la belleza absoluta sobre todas las cosas bellas de la tierra, y ennoblece el corazón haciéndolo reaccionar con repugnancia ante todos los sentimientos ruines de la humanidad"28.

Así mismo, en las notas editoriales se indicaba la manera de hacer la educación estética posible: "En la práctica de esta labor educativa debe aprovechar el maestro todos los elementos de la vida cuotidiana, principiando por aquellos que más directamente hieren los sentido externos. Es necesario que todo el ambiente escolar sea una permanente lección objetiva de alegría y de belleza; que las amarillentas paredes del aula se tornen en pulcras y gratas a la vista por la decoración artística y sencilla, trabajada por los mismos niños para que además del vinculo de la imagen atractiva tengan el placer de la propia obra; que el canto regocijado inicie y concluya la tarea de cada día, que la luz del sol penetre por ojivas y ventanas a iluminar el fácil afán de los párvulos; que las macetas de flores perfumen y purifiquen el aire y alegren la mirada con la multiplicidad de sus colores; que de la faz del maestro se borre el ceño agrio y terrible para dar paso a la

${ }^{25}$ CONTRALORIA GENERAL DE LAREPUBLICA. Censo General de Población 5 de julio de 1938, Tomo VIII Departamento del Huila. Bogotá, Ed Minerva, 1941, pág. 96-99.

${ }^{26}$ GACETA OFICIAL. Ordenanza Número 6 del 6 de Marzo de 1925 en Ordenanzas Asamblea Departamental del Huila 1921-1929. Neiva, Ed Imprenta Oficial, 1925, pág. 7 .

${ }^{27}$ Ibidem, pág. 7-8. Las cursivas son de mi autoría.

${ }^{28}$ CUENCA C. . Carlos A. y DURAN C., Marco E. Alegremos y embellezcamos nuestras escuelas en Revista Alfa. Organo de la Dirección de Educación Pública, Serie $1^{a}$. Número $2^{\circ}$. Neiva, Ed. Dirección de Educación Pública-Imprenta Oficial, Septiembre 15 de 1939 , pág. 3. 
serenidad que corrige y a la bondad que aconseja, y que la escuela proyecte su alegría más allá del poblado y de la aldea, hasta la última choza de la cañada donde el padre labrador prepara la tierra donde han de germinar las plantas"29.

En el mismo tono, avizoraba eventuales consecuencia de este tipo de educación para el conjunto de la sociedad neivana, "Si desde la escuela llevamos al corazón popular un sano sentido de la alegría del vivir y una noble comprensión de la belleza, algún día nuestro pueblo se sentirá poseído de una fuerza extraña y superior y amará más hondamente la tierra lo sustenta y el cálido cielo de la patria. Entonces el pueblo mismo se bastará a si mismo, hallará en la naturaleza la fuente de las más nobles alegrías y no dejará precipitar sus ocios en la oscura taberna donde se desbordan el regocijo artificial y degradante" ${ }^{\prime 30}$.

El Gobierno Departamental reglamenta, a través del Decreto Número 286 del 31 de Julio de 1950, la enseñanza del dibujo en el sistema de enseñanza rural: el dibujo "como actividad manual deberá ser combinado con la lectura y los demás aspectos del lenguaje. Igualmente podrá ser de inventiva o imaginativo y libre, especialmente de seres animados e inanimados, con colorido. También se enseñarán en las escuelas del campo el dibujo de lineación (sic), de copia, de interpretación de cuentos, fabulas, poesías etc. Dibujo de animales, plantas, contornos de hojas, frutas y de algunas partes del cuerpo. Además, perfil de algunos detalles de flores, animales, paisaje sencillo y objetos con líneas de lápiz". Con ello, esta área educativa reservada para las juventudes urbanas, se amplió a las campesinas.

La educación artística poco a poco fue encontrando su nicho específico dentro de las áreas de estudio; con lo cual se crearon soportes didácticos que contribuyera de manera efectiva al aprendizaje de los jóvenes neivanos. En consonancia, en los años 60 los docentes no desarrollaron "el dibujo del natural" sino la "copia de láminas", posiblemente suministradas por los fabricantes del "cuaderno de dibujo" de la marca "lbérica".

El Gobierno Departamental reglamenta, a través del Decreto Número 286 del 31 de Julio de 1950, la enseñanza del dibujo en el sistema de enseñanza rural: el dibujo "como actividad manual deberá ser combinado con la lectura y los demás aspectos del lenguaje. Igualmente podrá ser de inventiva o imaginativo y libre, especialmente de seres animados e inanimados, con colorido. También se enseñarán en las escuelas del campo el dibujo de lineación (sic), de copia, de interpretación de cuentos, fabulas, poesías etc. Dibujo de animales, plantas, contornos de hojas, frutas y de algunas partes del cuerpo. Además, perfil de algunos detalles de flores, animales, paisaje sencillo y objetos con líneas de lápiz" ${ }^{\prime 1}$.

Con ello, esta área educativa reservada para las juventudes urbanas, se amplió a las campesinas.

La educación artística poco a poco fue encontrando su nicho específico dentro de las áreas de estudio; con lo cual se crearon soportes didácticos que contribuyera de manera

\footnotetext{
${ }^{28}$ CUENCA C., Carlos A. y DURAN C., Marco E. Alegremos y embellezcamos nuestras escuelas en Revista Alfa. Órgano de la Dirección de Educación Pública, Serie $1^{\text {a }}$. Número $2^{\circ}$. Neiva, Ed. Dirección de Educación Pública-Imprenta Oficial, Septiembre 15 de 1939, pág. 3.

${ }^{29}$ lbidem.

${ }^{30}$ bidem

${ }^{31}$ GACETA DEL HULLA. Número 2064. Neiva, Ed. Imprenta Departamental, Agosto 26 de 1950. Pág. 373.
} 
efectiva al aprendizaje de los jóvenes neivanos. En consonancia, en los años 60 los docentes no desarrollaron "el dibujo del natural" sino la "copia de láminas", posiblemente suministradas por los fabricantes del "cuaderno de dibujo" de la marca "lbérica".

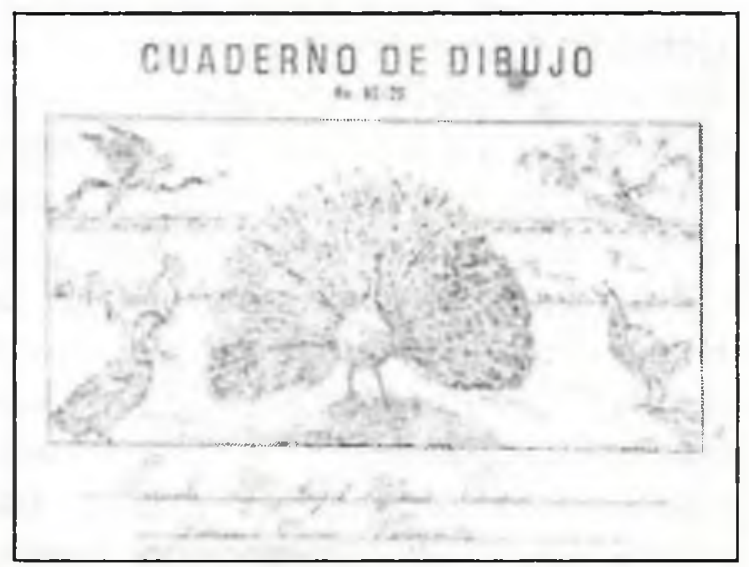

Cuaderno de dibujo $\mathrm{N}^{\circ}$ 60-20, marca lberia, perteneciente al historiador Ananias Osorio Valenzuela, Escuela Municipal Ángel Maria Paredes, 1963. Fuente cuaderno de dibujo perteneciente al historiador Ananias Osorio Valenzuela.

Si bien el esfuerzo didáctico ejercido por el docente era mínimo para el desarrollo de las capacidades representativas con lápices de grafito, tinta china y lápices de color, estos ejercicios brindaban la oportunidad de poner en contacto a los jóvenes neivanos con obras universales, provenientes disímiles épocas como La Gioconda de Leonardo da Vinci, Retrato de una dama desconocida de Antonio Pollaiuolo, Autorretrato con la cabeza vendada de Vincent Van Gogh, interpretadas y tituladas de manera libre por los estudiantes.

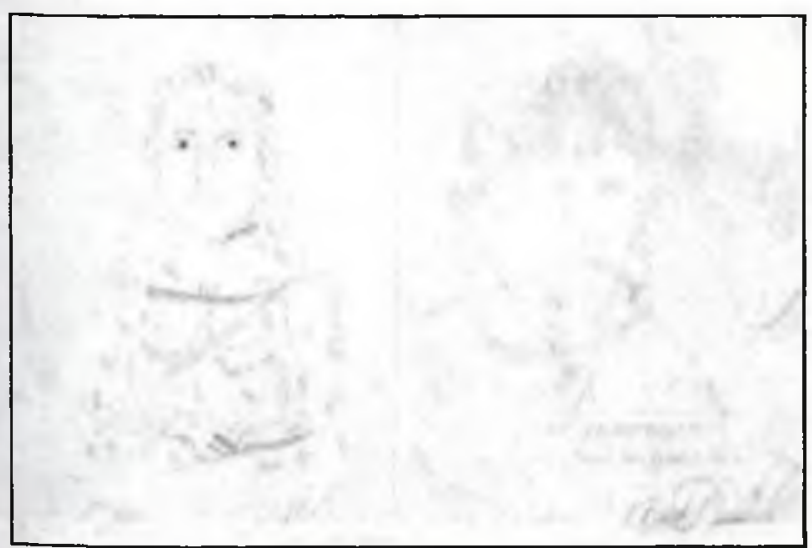

La Gioconda. Autor: Ananias Osorio Valenzuela, 1963, tinta china, $19 \times$ $13,5 \mathrm{~cm}$. El Fumador. Autor: Ananias Osorio Valenzuela, 1963, lápiz de grafito, $19 \times 13,5 \mathrm{~cm}$. Fuente: Cuaderno de dibujo perteneciente al historiador Ananias Osorio Valenzuela.
Además, a través de los dibujos los niños reforzaban los valores patrios con las representaciones de la bandera, el escudo y los héroes nacionales; las creencias religiosas y los principios de solidaridad con los desposeídos, por medio de las respectivas imágenes. Motivaban la imaginación por medio de la interpretación gráfica de frases o fragmentos de poemas. Complementaban la enseñanza del dibujo los ejercicios con composiciones geométricas y la delineación de figuras siguiendo estructuras de líneas, previamente impresas. Finalmente, trabajaban elementos básicos de la teoría del color y de la música.

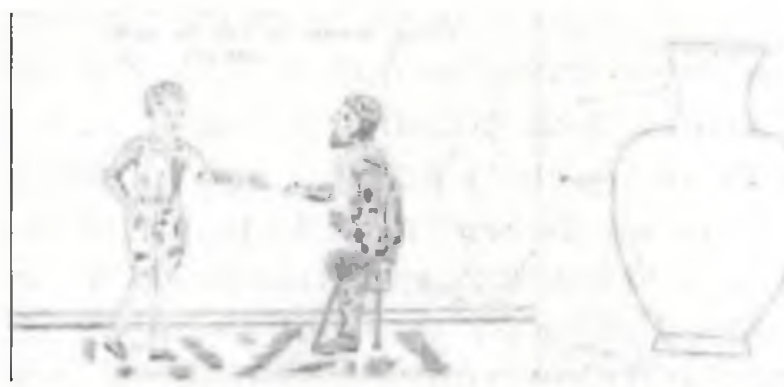

La limosna. Autor: Ananías Osorio Valenzuela, 1963, tinta china y lápices de color, $18,5 \times 13,5 \mathrm{~cm}$. Jarrón (fragmento). Autor: Ananías Osorio Valenzuela, 1963 , lápiz de color rojo, $19 \times 13,5 \mathrm{~cm}$. Fuente: Cuaderno de dibujo perteneciente al historiador Ananias Osorio Valenzuela.

1.2 Los fotograbados, grabados e ilustraciones de los textos escolares

Gracias a la sucesiva expansión del sistema educativo, en las décadas de los años 30 a 50, ante todos los estamentos sociales de Neiva debieron estar expuestos los magníficos fotograbados, grabados e ilustraciones contenidos en los textos escolares como: 1) la Historia de Colombia ${ }^{32}$. 2) el Catecismo ${ }^{33}$ y la Historia Sagrada. 3) la Cartilla Moderna de

\footnotetext{
${ }^{32} \mathrm{HENAO}$, Jesús Maria y ARRUBLA, Gerardo. Historia de Colombia para la enseñanza secundaria. Tercera edición. Bogotá. Ed. Libreria Colombiana Camacho Roldán \& Tamayo, 1920.

${ }^{33}$ F.T.D. Doctrina Cristiana. Curso superior. México, Ed. Progreso S.A., 1954.

FTD coincide con las siglas correspondientes a Frére Theophane Durand (Louis-Adrien Durand) el Superior General de la Congregación de los Hermanos Maristas, quien ejerció funciones entre 1883 y 1907. En 1920 "FTD" se convirtió en el nombre de la editorial y en 1932 se cambió por "Editorial Luis Víves".
} 
Urbanidad para Niños ${ }^{34}$ y Niñas $^{35} .4$ ) las Nociones Elementales de Geometría Aplicadas al Dibujo Lineal ${ }^{36}$. 5) demás textos escolares. En el primero predominaban fotograbados de los personajes patrios y los grandes hechos históricos; los segundos se caracterizaban por los grabados con técnicas de buril o talla dulce, impresos en blanco y negro; en las terceras se emplearon series de cuadros narrativos, con un tipo de dibujo cercano a la caricatura y coloración en planos blancos, terracota y negro; en el cuarto y en los quintos se exponian ilustraciones en blanco y negro o dibujos con policromías.

Consideramos que a través de las imágenes y los textos se buscaba que la "Historia de Colombia para la enseñanza secundaria" contara su objeto y su fin a las jóvenes generaciones de Neiva. "Ella presenta el pasado, pone ante los ojos lo que los hombres pensaron y sintieron, su labor en provecho personal y en el de la posteridad. Contribuye a la formación del carácter, moraliza, aviva el patriotismo y prepara con el conocimiento de lo que fue a la activa participación del presente. Inapreciable es, pues, su valor educativo: cultiva eficazmente la memoria y la imaginación; ilustra la razón y la conciencia, y fortalece la voluntad; da variadas y múltiples lecciones instructivas y recreativas; pone al futuro ciudadano en capacidad de formar opiniones precisas y sanas, para quedar cubierto de las influencias dañosas de la ignorancia y de la credulidad que oscurecen la verdad y comprometen la paz y el orden"37.

\footnotetext{
${ }^{34}$ F.T.D. Cartilla Moderna de Urbanidad para Niños. Barcelona, 1929. ${ }^{35}$ F. T.D. Cartilla Moderna de Urbanidad para Niñas. Barcelona, 1929. ${ }^{36}$ BRUÑO, G. M. Nociones Elementales de Geometría Aplicadas al Dibujo Lineal. Medellin, Ed. Bedout, 1955. G.M. Bruño es el seudónimo del Hermano Lasallista Miguel Febres Cordero.

${ }^{37} \mathrm{HENAO}$, Jesús María y ARRUBLA, Gerardo. Historia de Colombia para la enseñanza secundaria. Tercera edición... Op. Cit. pág.

${ }^{38}$ ABENZA RODRIGUEZ, Aureliano. La pedagogia y la escuela en Francia, Suiza y Alemania. Buenos Aires, ED. Biblioteca Virtual Universal, 2003. http://www. biblioteca.org.ar/autor.asp?texto =a Consultada Marzo 18 de 2011.
}

Detrás de ello, parece resonar alguna recomendación de orden didáctico: "los niños y el maestro tienen el tratado de historia abierto por la página donde está la lección respectiva de aquel día. El maestro o el niño leen un párrafo, que después el primero detenidamente explica, pero no para añadir nada que el libro no ponga, sino generalmente para aclarar conceptos o para señalar las particularidades del asunto. Para esto último suele hacer que los niños se fijen en los grabados, explicándoles también, entonces, quienes son los personajes retratados y haciendo notar el cargo, posición social, actitud, etc., de los individuos que, en el hecho histórico de referencia, intervinieron y que en el grabado figuran. Después de la explicación vienen, como es natural, la preguntas para saber el concepto que los alumnos han formado del asunto"38.

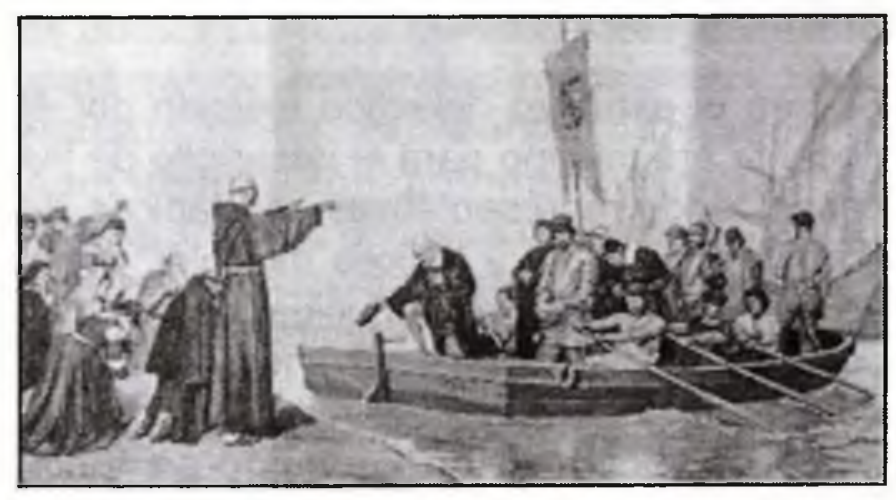

Partida Colón desde el Puerto Palos para el Descubrimiento de América. Autor: Antonio Gisbert Pérez, 1875, Fotograbado.

Fuente: HENAO, Jesús Maria y ARRUBLA, Gerardo. Historia de Colombia para la enseñanza secundaria. Tercera edición. Bogotả. Ed. Librería Colombiana Camacho Roldán \& Tamayo, 1920, pág. 21.

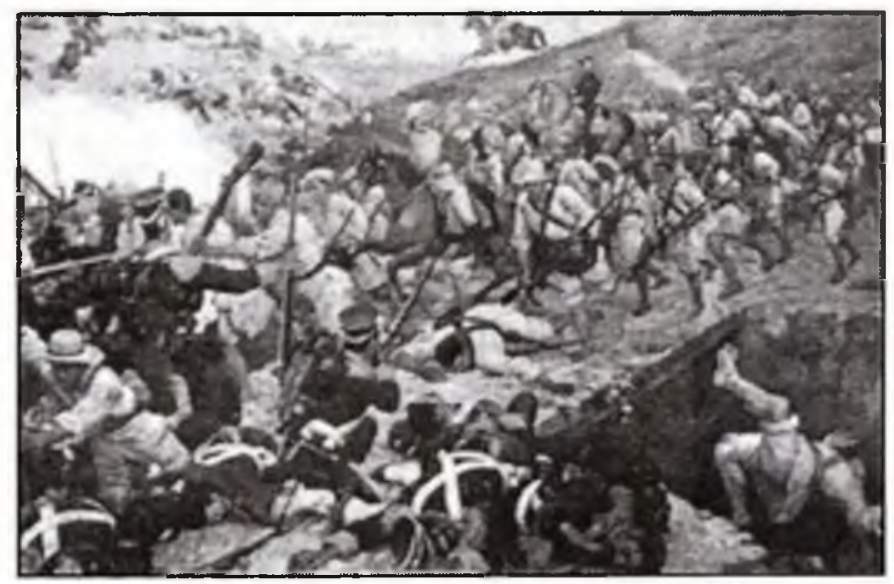

Batalla de Boyacá (Detalle). Autor: Martín Tovar Tovar. 1890, Oleo sobre tela Fuente: HENAO, Jesús Maria y ARRUBLA, Gerardo. Historia de Colombia para la enseñanza secundaria. Tercera edición. Bogotá. Ed. Libreria Colombiana Camacho Roldán \& Tamayo, 1920, pág. 384. 
La mencionada Historia de Colombia se encuentra ilustrada con 154 imágenes, correspondientes a 75 retratos de personajes ilustres, 20 pinturas de artistas internacionales y nacionales, 15 esculturas de disímil factura, 11 representaciones arquitectónicas, 8 objetos precolombinos, 6 escenas históricas, 6 escudos de armas, 4 facsímiles de documentos originales, 3 ilustraciones de navíos, 2 dibujos de instrumentos de navegación, 2 diseños de medallas. Así mismo, menciona la importancia de las artes durante la Colonia (pág. 184); destaca el Taller de pintura de Mariquita, creada por la Expedición Botánica (pág. 234); y resalta los aportes visuales de la Comisión Corográfica (pág. 520). Con ello, se superó con creces los limitados recursos didácticos de los libros para la enseñanza de la historia del siglo XIX ${ }^{39}$

Acerca de los catecismos, editados con el fin de afirmar la fe, se debe aclarar que inicialmente solo se imprimían para el uso de los sacerdotes ${ }^{40} y$, posteriormente se difundieron a la feligresía. En cuanto a la ciudad, tuvieron que memorizar el "Catecismo de la Doctrina Cristiana. Curso superior" varias generaciones de estudiantes neivanos, hasta los años 60 del siglo XX.

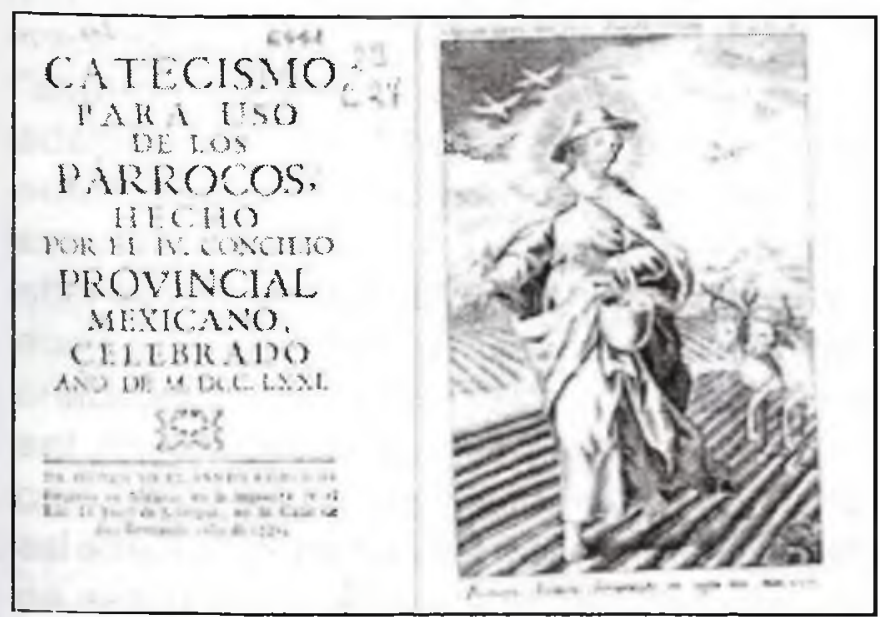

Carátula e imagen de un catecismo para el uso de los sacerdotes. Autor anónimo. 1772, Xilografia, impresión en blanco y negro.

Fuente: SANTO CONCILIO. Catecismo para uso de los párrocos. Hecho por el IV Concilio Provincial Mexicano celebrado en el año MDCCLXXI. México, Ed. Imprenta de el Lic. D. Josef de Jáuregui, en la Calle de San Bernardo, 1772.
De los 76 grabados contenidos en este catecismo, 57 corresponden a ilustraciones de dogmas y representaciones religiosas, mientras que 19 describen aspectos de la cotidianidad de la vida francesa, relacionada con las prácticas católicas durante las primeras décadas del siglo XX. Como la edición del catecismo escolar pertenece a los Hermanos Maristas, se puede inferir que la autoría de las ilustraciones corresponde a grabadores franceses e italianos ${ }^{41}$.

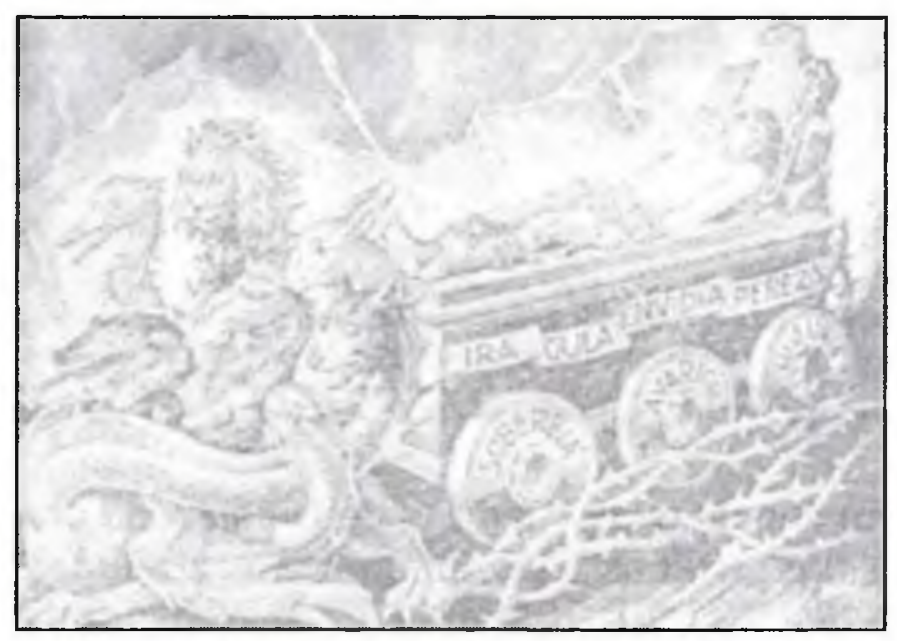

Los siete pecados capitales arrastran al hombre hacia la eterna perdición. Autor: Conti, Grabado dulce e impresión en Blanco y Negro, 1954. Fuente: F.T.D. Doctrina Cristiana. Curso superior. México, Ed. Progreso S.A., 1954, pág. 193

En esta dinámica, dicha congregación comenzó a publicar libros escolares desde 1890, traducidos al español de la lengua original. Además, pudieron trasladar copias de las láminas de cobre a México, donde se producían y distribuían los textos escolares a otros países latinoamericanos. De hecho, entre 1899 y 1914 en la Congregación Marista de la "ciudad de Mérida...se destacaron los maestros franceses

\footnotetext{
${ }^{39}$ ROCHA DALLOS, Silvia Juliana. La escritura de los manuales escolares de historia en Colombia durante la segunda mitad del siglo XIX. Bucaramanga. Tesis Universidad Industrial de Santander-Facultad de Ciencias Humanas-Escuela de Historia, 2008, pág. 188-226.

40 SANTO CONCILIO. Catecismo para uso de los párrocos. Hecho por el IV Concilio Provincial Mexicano celebrado en el año MDCCLXXI. México, Ed. Imprenta de el Lic. D. Josef de Jáuregui, en la Calle de San Bernardo, 1772.

${ }^{41}$ F.T.D. Docrina Cristiana. Curso superior. Op. Cit.
} 
Clemente Reivisat, Marcelino T. Bonett, al frente del taller de artes gráficas...En esta escuela habia talleres de carpintería, herreria, mecánica e imprenta" ${ }^{42}$.

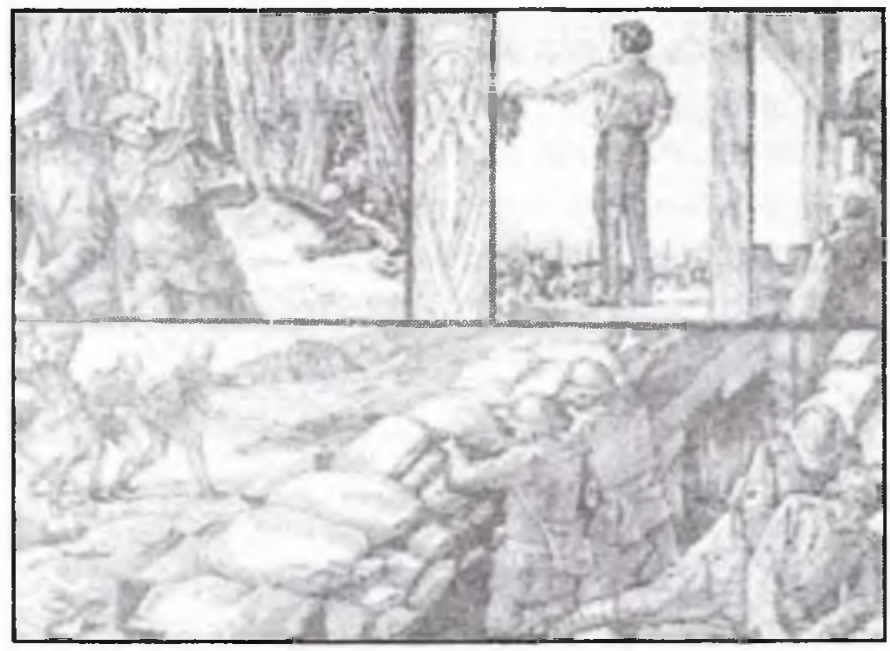

Homicidio. Ejecución de un condenado a muerte Un campo de batalla. Autor U.L. Grabado dulce e impresión en Blanco y Negro, 1954. Fuente: F.T.D. Doctrina Cristiana. Curso superior. México, Ed. Progreso S.A., 1954, pág. 145.

En cuanto a las "Cartillas de Urbanidad para Niños y Niñas", las imágenes reproducen dibujos que dan cuenta de las calidades visuales relacionadas con el diseño grafico y un lenguaje muy próximo a la caricatura; posiblemente empleados como estrategia motivadora, encaminada a centrar la atención y la fijación de patrones de comportamiento en las nuevas generaciones neivanas. La cartilla para niños tiene un total de 130 ilustraciones, mientras la de niñas posee 136 gráficas.

Las temáticas son similares en ambas cartillas. Para ello, también debemos considerar que el fin último de las Cartillas de Urbanidad, consistía en fomentar en la niñez y juventud neivana la asunción de roles sociales de las "naciones más civilizadas", no en vano los dibujos duplicaban episodios de la sociedad francesa, pertenecientes a clases pudientes de los años
30. Asi mismo, se acompañaban las lecciones con cortas lecturas ejemplares y sus correspondientes ilustraciones; llegando a contener, en menor proporción, secuencias de 4 imágenes.

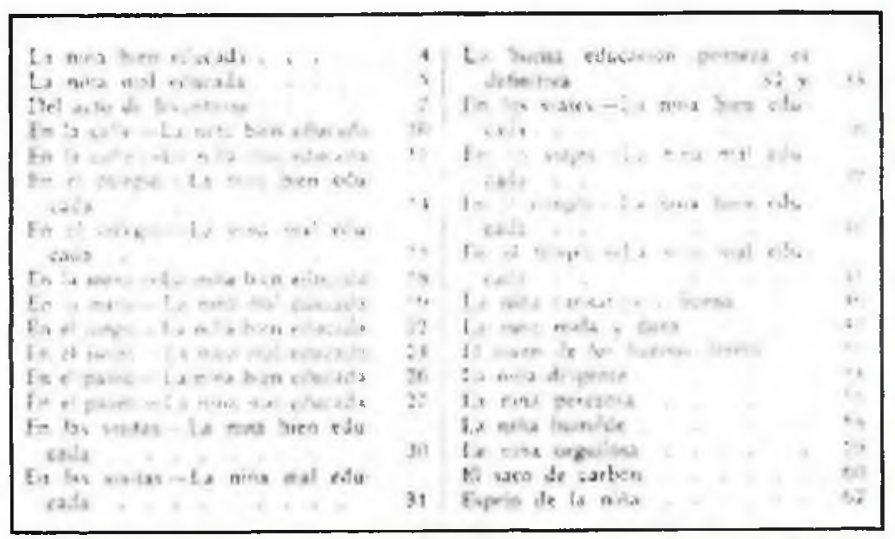

Lista de los temas e ilustraciones de la Cartilla Moderna de Urbanidad para Niñas. Fuente: Cartilla Moderna de Urbanidad para Niñas. Barcelona, Editorial FTD, 1929, pág. 64 .

\section{Temas e ilustraciones}

Una explicación más amplia sobre la función de las cartillas de urbanidad la ofrece Santiago Castro Gómez: "Los manuales de urbanidad se convierten en la nueva biblia que indicará al ciudadano cuál debe ser su comportamiento en las más diversas situaciones de la vida, pues de la obediencia fiel a tales normas dependerá su mayor o menor éxito en la civitas terrena, en el reino material de la civilización. La "entrada" en el banquete de la modernidad demandaba el cumplimiento de un recetario normativo que servía para distinguir a los miembros de la nueva clase urbana que empezaba a emerger en toda Latinoamérica...Ese "nosotros" al que hace referencia el manual es, entonces, el ciudadano burgués, el mismo al que se dirigen las constituciones republicanas; el que sabe cómo hablar, comer, utilizar los cubiertos, sonarse las narices, tratar a los sirvientes, conducirse en

${ }^{42}$ PÉREZ SILLER, Javier y CRAMAUSEL, Chantal. México Francia: Memoria de una sensibilidad común, siglos XIX y XX, Volumen 2 . Michoacán, Ed. Colegio de Michoacán, 2004, pág. 227-228. 
sociedad. Es el sujeto que conoce perfectamente "el teatro de la etiqueta, la rigidez de la apariencia, la máscara de la contención"...El "proceso de la civilización" arrastra consigo un crecimiento del umbral de la vergüenza, porque se hacía necesario distinguirse claramente de todos aquellos estamentos sociales que no pertenecian al ámbito de la civitas que intelectuales latinoamericanos como Sarmiento venían identificando como paradigma de la modernidad. La "urbanidad" y la "educación cívica" jugaron, entonces, como taxonomías pedagógicas que separaban el frac de la ruana, la pulcritud de la suciedad, la capital de las provincias, la república de la colonia, la civilización de la barbarie"43.
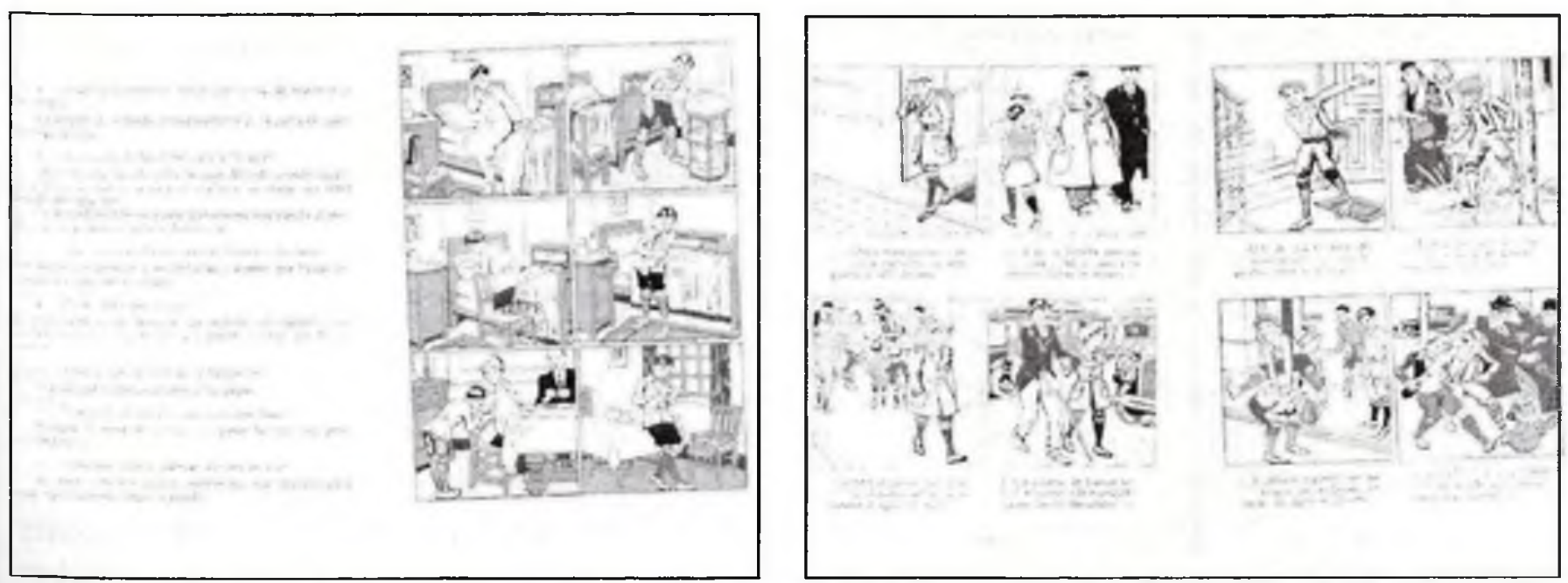

Del acto de levantarse y del aseo. En la calle- el niño bien educado y en la calle - el niño mal educado. Ilustraciones Cartilla Moderna de Urbanidad para Niños. Fuente: Cartilla Moderna de Urbanidad para Niños. Barcelona, Editorial FTD, 1929, pág. 6-7 y 10-11.
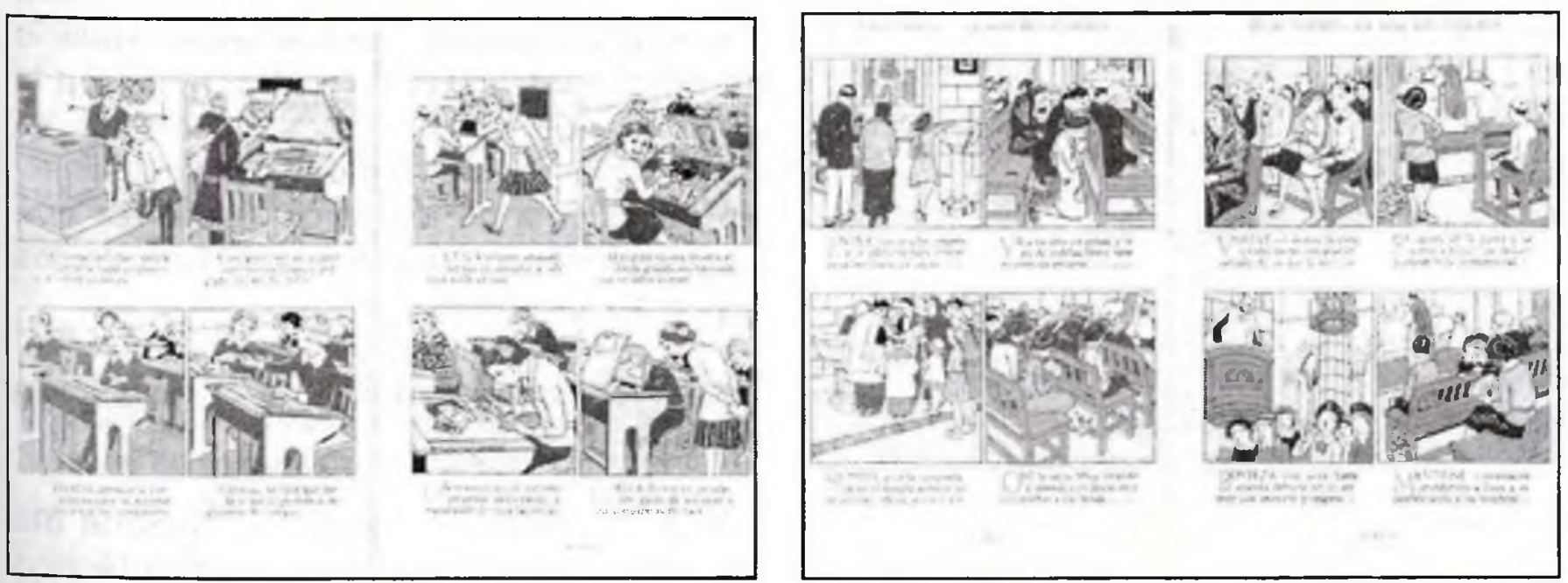

En el colegio- la niña bien educada y en el colegio- la niña mal educada. En el templo - la niña bien educada y en el templo - la niña mal educada. Ilustraciones de Cartilla Moderna de Urbanidad para Niñas.

Fuente: Cartilla Moderna de Urbanidad para Niñas. Barcelona, Editorial FTD, 1929, pág. 14-15 y 40-41.

${ }^{43}$ CASTRO-GÓMEZ, Santiago. Ciencias sociales, violencia epistemica y el problema de la "invención del otro" en LANDER, Edgardo (comp.). La colonialidad del saber: eurocentrismo y ciencias sociales. Perspectivas Latinoamericanas. Buenos Aires, Ed. CLACSO, Consejo Latinoamericano de Ciencias Sociales, 2005. pág. 150. 
Probablemente, los encargados de diseñar estos libros educativos consideraban que los textos escritos cobraban mayor eficacia, si se implementaban didácticamente como los catecismos; basados en preguntas y respuestas que se debian repetir y memorizar. Además, si las representaciones se desarrollaban a manera de secuencia y se establecían comparaciones, a nivel de forma, entre las actitudes y comportamientos sociales "incorrectos y correctos". Estas secuencias, en distinto orden, contenian series de 4, 6, 8, 9, 10 y 12 imágenes en las cartillas de los niños; cuando las sucesiones de $4,6,8,10$ y 12 dibujos se presentan en las cartillas de las niñas; los dos tipos de cartillas contienen varias ilustraciones individuales.

De otra parte, la legislación educativa determinada a nivel nacional en $1903^{44}$ y departamental en 1911-191445 y el Decreto Número 45 del 26 de Septiembre de $1916^{46}$, ordenan a las instituciones educativas implementar las "Nociones elementales de Geometría aplicadas al Dibujo lineal". Para ello el texto de estudio se organizó en cuatro apartados con los siguientes títulos: Libro Primero: Líneas y ángulos. Libro segundo: Circunferencia. Libro Tercero: Superficies. Libro Cuarto: Sólidos.

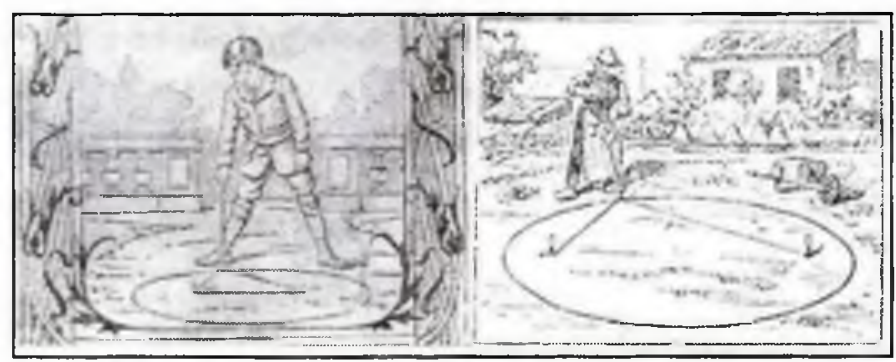

Carátula (Detalle). Libro Nociones Elementales de Geometria Aplicadas al Dibujo Lineal. Ilustración impresa en Blanco y Negro sobre papel verde claro, 1955. Elipse del jardinero. Ilustración impresa en Blanco y Negro, 1955. Fuente: BRUÑO, G. M. Nociones Elementales de Geometría Aplicadas al Dibujo Lineal. Medellín, Ed. Bedout, 1955, carátula y pág. 56.

Cada apartado contiene las respectivas aplicaciones, que versan sobre el uso de instrumentos de medición; el trazo de distintas líneas, ángulos y superficies; dibujo de arcos, cuerdas y tangentes; diseño de molduras y detalles de columnas empleadas en la arquitectura; cálculo de áreas regulares e irregulares; construcciones de sólidos y cálculos de aéreas y volúmenes de los sólidos. Para ello se emplea un total de 190 ilustraciones, realizada en blanco y negro.

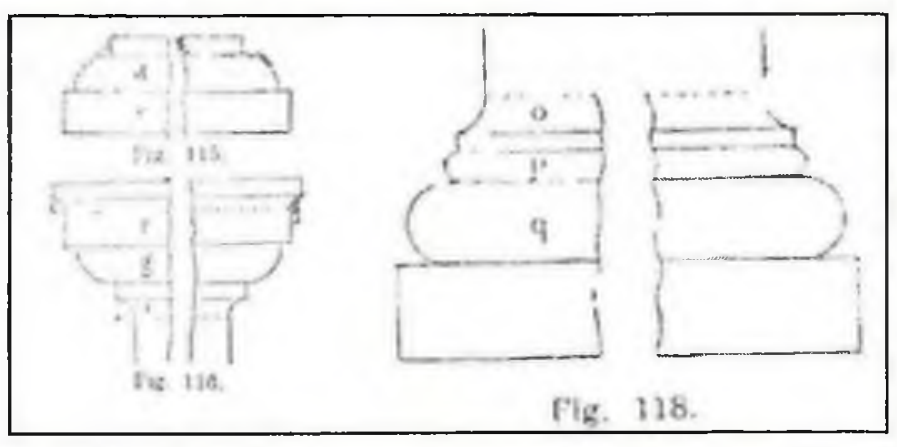

Fig. 115. Plinto, orlo o lastro (cuadro ubicado en la base de la columna). Fig. 115. Ceja (moldura que encuentra en los capiteles). Fig. 118. Toro o Bocel (moldura circular y convexa de la base de una columna).

llustraciones impresas en Blanco y Negro, 1955. Fuente: BRUÑO, G. M. Nociones Elementales de Geometria Aplicadas al Dibujo Lineal. Medellin, Ed. Bedout, 1955, pág. 52 y 53 .

En relación a las sospechas que pudieran existir sobre la cantidad de textos que pudiesen haber circulado en la población neivana, podemos decir que el estamento gubernamental se encargo de establecer bibliotecas públicas para tal fin. Exactamente, en 1938 el Anuario Estadístico del Municipio de Neiva registra la existencia de las siguientes bibliotecas, su localización y la cantidad de 1451 volúmenes; sin dar cuenta de los libros existentes que pudiesen encontrarse en cada uno de los hogares. (ver cuadro siguiente).

\section{La institucionalización de la educación visual}

2.1 La "Sección de Extensión Cultural del Departamento" y la creación del Instituto Técnico Universitario Surcolombiano ITUSCO

${ }^{44}$ Ley 39 de Octubre 26 de 1903 y Decreto Reglamentario N ${ }^{\circ} 491$ de Junio 3 de 1904, Articulo 69.

${ }^{45}$ GACETA OFICIAL. Ordenanzas de laAsamblea del Huila 1911-1914. ..Op. Cit., pág. 000045 .

${ }^{46}$ GACETA DEL HUILA. Número 369. Decreto Número 45 del 26 de Septiembre de 1916... Op. Cit., pág. 548-550. 
Bibliotecas de Neiva-1938 ${ }^{47}$

\begin{tabular}{|l|l|l|l|l|l|}
\hline $\begin{array}{c}\text { CENTRO HUILENSE DE } \\
\text { HISTORIA } \\
\begin{array}{c}\text { (Ubicación: Edificio Colegio } \\
\text { Santa Librada) }\end{array}\end{array}$ & COLEGIO SANTA LIBRADA & \multicolumn{2}{c|}{$\begin{array}{c}\text { CULTURA ALDEANA } \\
\text { (Ubicación: Edificio Palacio } \\
\text { Nacional) }\end{array}$} \\
\hline Libros & Cantidad & Libros & Cantidad & Libros & Cantidad \\
\hline Historia & 265 & Historia & 52 & Temas varios & 105 \\
\hline Literatura & 69 & Literatura & 35 & & \\
\hline Autores clásicos & 27 & Autores clásicos & 5 & & \\
\hline Religión & 28 & Religión & 14 & & \\
\hline Ciencias naturales & 48 & Ciencias naturales & 12 & & \\
\hline Legislación & 210 & Derecho & 24 & & \\
\hline Biblioteca infantil & 183 & Biblioteca infantil & 210 & & \\
\hline Poesía & 13 & Enciclopedias & 49 & & \\
\hline Teatro & 5 & Geografía & 23 & & \\
\hline Novelas & 14 & Filosofía & 5 & & \\
\hline Agricultura & 22 & Pedagogía & 20 & & $\mathbf{1 0 5}$ \\
\hline & & Artes manuales & 3 & & \\
\hline & & Biblioteca Aldeana & 91 & & \\
\hline
\end{tabular}

Desde el ámbito institucional un hecho fundamental para la promoción y difusión cultural de Neiva se produjo en 1948, cuando la Asamblea Departamental creó y reglamentó la "Sección de Extensión Cultural del Departamento" mediante la Ordenanza № 16 del 23 de Diciembre. Esta determinación será la base para la posterior creación del Instituto Huilense de Cultura como un ente autónomo, encargado de formar los artistas visuales y difundir sus trabajos. Dada la trascendencia de la mencionada Ordenanza vale la pena registrarla.

"Artículo $1^{\circ}$. Créase en el Departamento la Sección de Extensión Cultural, dependiente de la Dirección de Educación. Esta dependencia estará servida por un Director-Jefe y una Mecanógrafa-Bibliotecaria.
Artículo $2^{\circ}$. Son funciones del Director Jefe:

a) Promover todo lo referente al desarrollo intelectual y artístico del Departamento.

b) Dirigir la Biblioteca "Olegario Rivera".

c) Dirigir la publicación de una revista mensual de divulgación del Huila en sus diferentes aspectos.

d) Dirigir la publicación de obras de autores huilenses, a juicio de la Honorable Junta de que se hablará adelante.

e) Organizar ferias del libro, días culturales y patrocinar conciertos, obras teatrales, etc. Que contribuyan decisivamente a formar una conciencia cultural.

f) Fomentar la organización y marcha de un centro intelectual huilense al cual servirá como secretario.

Artículo $3^{\circ}$. Créase una Junta de Fomento Cultural del Huila, la cual estará integrada por

${ }^{47}$ RIVERA S. Alejandro. Anuario estadístico del Municipio de Neiva. Entrega 1 Relativo al año de 1938. Manizales. Ed. República de ColombiaDepartamento del Huila-Tipografia Éxito, Agosto 1939, pág. 102. 
los miembros de la Conciliatura del Liceo Femenino de Santa Librada y el Director de Extensión Cultural.

Artículo $4^{\circ}$. Son funciones de la Junta:

a) Trazar el plan de las labores del Director de Extensión Cultural.

b) Seleccionar los pedidos de los libros para la Biblioteca Departamental "Olegario Rivera".

c) Decidir sobre las obras que deban publicarse en la selección de autores huilenses. d) Actuar como Junta de Censura para los actos de que trata el inciso d) del artículo $2^{\circ}$ de la presente ordenanza.

e) Fomentar los deportes con cuyo fin creará juntas especiales en cada municipio. f) Decidir todos los puntos que el Director de Extensión Cultural someta a su consideración.

g) Autorizar al Jefe para celebrar contratos en desarrollo de las manifestaciones culturales; $y$.

h) Nombrar el Jefe de Extensión Cultural y a la Mecanógrafa Bibliotecaria.

Artículo $5^{\circ}$. Los autores que publiquen obras dentro de la selección de autores huilenses de que trata el inciso d) del artículo $2^{\circ}$ tendrá derecho a 80 ejemplares gratuitos y podrá ordenar una mayor edición, que el Departamento cobrará a precio de costo.

Artículo $6^{\circ}$. Créase el Fondo de Cultura Huilense formado por quince mil pesos $(\$ 15.000$, ) que se incluirán en el próximo presupuesto. $Y$ por el valor de la propaganda de la revista, de la propaganda de las contraportadas de las obras que se publiquen y del rendimiento que dejen las actividades propias de la entidad.

Parágrafo. Las entradas de que trata el presente artículo ingresarán a la Tesorería General del
Departamento y se contabilizará en la cuenta especial del Fondo de Cultura.

Artículo $7^{\circ}$. Del Fondo de Cultura Huilense se atenderá en preferencia los siguientes gastos: Sueldo del Director-Jefe a $\$ 400$ mensual Sueldo de la Mecanógrafa-Bibliotecaria 140-oo

Aporte para la revista $200-00$

Con el remanente se atenderá a otros gastos contemplados en la presente ordenanza.

Artículo $8^{\circ}$. Destinase la suma de mil pesos $(\$$ $1.000,00)$ para adquirir la placa que en representación del Huila se ha de colocar en la casa del Maestro Valencia, en Popayán hoy monumento nacional.

Artículo $9^{\circ}$. Destinase la suma de tres mil pesos $(\$ 3.000,00)$ para el monumento, que en los cuarteles del Ejército acantonado en Neiva, se levantará al héroe huilense "Cándido Leguízamo", y tres mil pesos $(\$ 3.000,00)$ para el monumento que en honor del doctor Pedro Pablo Anzola se levantará en el cementerio central de Neiva.

Parágrafo. Las anteriores sumas, que deberán incluirse en el presupuesto que elabores la presente Asamblea, podrán ser cobradas por el Comandante del ejército acantonado en Neiva y por la Junta constituida pro-monumento Pedro Pablo Anzola, respectivamente.

...Artículo $14^{\circ}$. Destinase la suma de quinientos pesos $(\$ 500,00)$ para la compra de unos ejemplares de la obra "Apuntes etnológicos y arqueológicos de San Agustín", por Tiberio López para la Biblioteca Cultural de que trata esta ordenanza y para ser repartida en las escuelas urbanas del Departamento"48 . 
Con el anterior documento se infiere que en esta época el Gobierno Departamental es el principal promotor de las artes visuales en los establecimientos, los espacios públicos y las iniciativas personales, que son empleadas para representar la imagen institucional. Por ejemplo, el Decreto $N^{\circ} 007$ Bis B. del 31 de Diciembre de 1948 especifica: "Artículo $1^{\circ}$. Nombrase al doctor Jesús Antonio Molina Vega representante por el Huila en el Congreso Eucarístico, que se verificará en la ciudad de Cali en el próximo mes de enero. Artículo $2^{\circ}$. El doctor Molina Vega, en su carácter anotado, expondrá la escultura del "Cristo Yacente" de que es autor"49. Con ello, el arte tridimensional se crea para exaltar los héroes locales, los hombres ilustres y las convicciones religiosas comunes.

En 1957 eran registrados los artistas huilenses que contribuian a la cultura nacional y local en los siguientes términos: "La pintura tiene cultivadores como Magola Vanegas de Bahamón, Martha Borrero de Borrero, Benedicto Ramírez y el sin para paisajista Ricardo Borrero Álvarez. En escultura se distingue el ingeniero Jesús A. Molina Vega"50. Aunque el Maestro Ricardo Borrero Álvarez ya había fallecido en 1931, el reconocimiento de su trabajo se había convertido para la fecha en un referente nacional.

Para la década de 1960 Neiva entraba de lleno en el proceso de modernización estructural, aunque aún predominaba la mentalidad de la cultura aldeana y rural. En otros términos, la urbe "empezaba a convertirse en una ciudad que despierta al urbanismo... Neiva sufría los naturales quebrantos de su transformación de aldea grande en pequeña ciudad. Se puede decir que la hija de Don Diego era primeriza, embarazada de progreso" ${ }^{51}$. De las grandes imaginaciones, imágenes y realidades de los prohombres de los años anteriores solo quedaban los últimos rezagos en los discursos oficiales. Ahora la ciudad contemporánea exigía la presencia permanente de los medios de comunicación; de hecho, se contaba con la Radiodifusora Nacional de Colombia desde 1940, la Televisora Nacional desde 1954 y la circulación de los rotativos tradicionales.

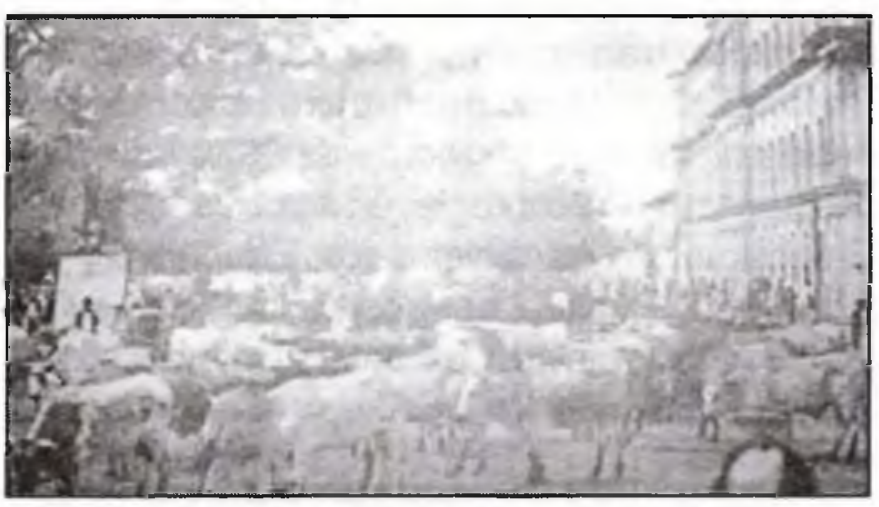

Aspecto que presentaba el Parque Santander frente al Palacio de las 56 ventanas, hacia 1945. Fuente: DIARIO DEL HUILA Año IX N²345, Julio 4 de 1975, pág. 1.

Asi mismo, los procesos culturales se encontraban dinamizados a nivel nacional por el Instituto Colombiano de Cultura (COLCULTURA), creado en 1968 mediante Decreto Ley 3154 ; cuyo Artículo $2^{\circ}$ definía su principal objetivo: "Corresponde al Instituto el fomento de las artes y las letras, el cultivo del Folclore nacional, el estímulo de bibliotecas, museos y centros culturales y la divulgación de la cultura nacional" 52 .

De otra parte, al Departamento del Huila poco a poco fue llegando el influjo de las políticas culturales determinadas desde los centros de poder, que aunadas a las exigencias educativas y culturales de los ciudadanos, dieron como resultado la fundación de las instituciones que

${ }^{49}$ GACETA DEL HUILA. Año XLII Número 2.024. Neiva, Ed. Imprenta Departamental, Marzo 25 de 1949, pág. 408.

${ }^{50}$ VARGAS MOTTA, Gilberto. El Huila. Reseña histörico geográfica. Neiva, Ed. Imprenta Departamental del Huila, 1957, pág.28.

${ }^{51}$ MORENO, Delimiro. Los Papelípolas. Ensayo sobre una generación poética. Bogotá, Ed. Vargas Editor, 1995, pág. 12.

${ }^{52}$ DIARIO OFICIAL. Decreto Número 3154 (26 de Diciembre de 1968). Por el cual se crean el Instituto Colombiano de Cultura y el Consejo Nacional de Cultura. Bogotá, 22 de Enero de 1969, pág. 89-90. 
jugaron un papel determinante dentro de los procesos formativos. En este sentido, fue decisiva la creación del Instituto Técnico Universitario Surcolombiano ITUSCO, mediante la Ley 55 del 17 de diciembre de 1968, con la misión de formar los profesionales que necesitaba la Región e investigar la realidad del entorno surcolombiano; también, la comunidad confiaba en que "esta formidable obra transforme la anhelada mentalidad de las nuevas clases dirigentes del Huila, la comarca que se proyecta hacia el verdadero futuro de Colombia"53. Este instituto inició labores académicas el 30 de marzo de 1970, con tres programas de Tecnología, en Administración de Empresas, en Administración Educativa y en Contaduria Pública. Luego, mediante la Ley 13 de 1976 adquirió el estatus de Universidad Surcolombiana USCO.

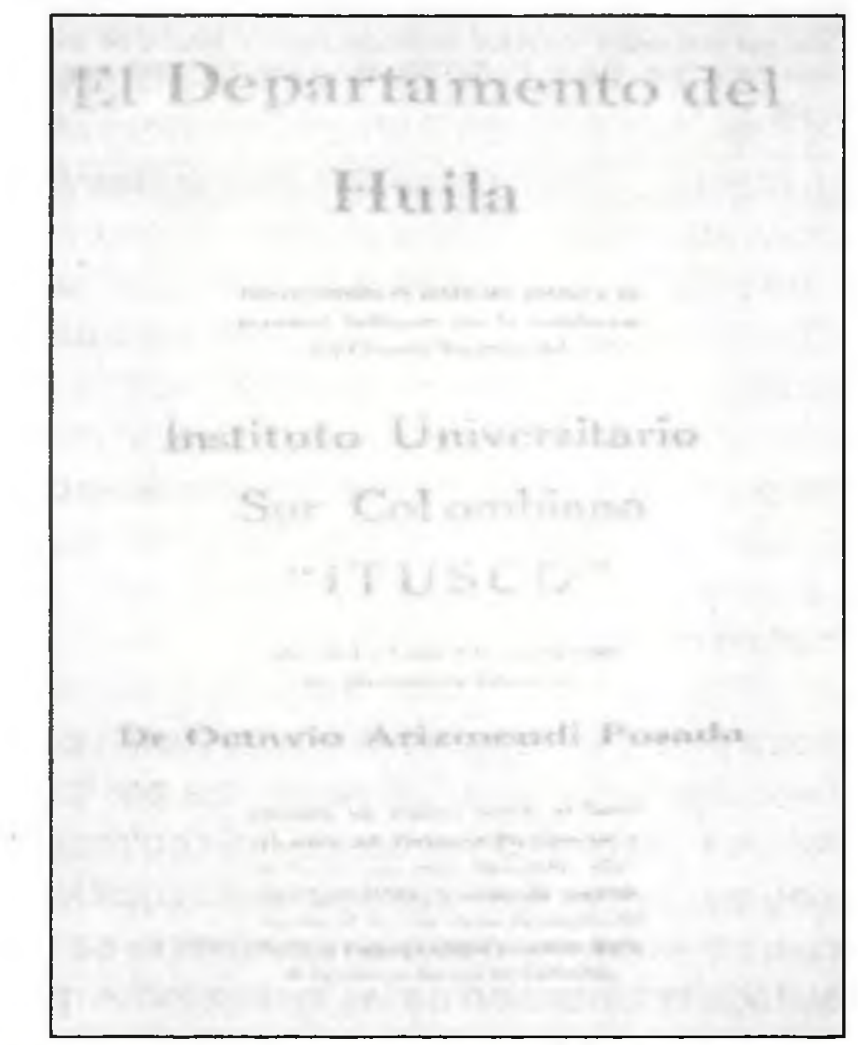

Saludo del Departamento del Huila al Ministro de Educación Octavio Arismendi Posada con motivo de la instalación del Consejo Superior Universitario del "ITUSCO". Fuente: DIARIO DEL. HUILA. Neiva, Martes 4 de Marzo de 1969.
La permanencia de la institucionalidad cultural se ve reflejada en la Ordenanza Numero 41 del 6 de Diciembre de 1968, mediante la cual se establecía el presupuesto para el funcionamiento del Gobierno Departamental, y la respectiva asignación de la partida para el trabajo de la Sección de Extensión Cultural de la Secretaría de Educación:

$\begin{array}{lrc}\text { 1 Director } & \$ 1.400 .00 \$ 16.800 .00 \\ \text { 1 Bibliotecaria } & 800.00 & 9.600 .00 \\ \text { 1 Administrador del } & & \\ \text { Museo } & 650.00 & 7.800 .00^{54}\end{array}$

\subsection{La "Escuela de Bellas Artes"}

Dentro de las políticas culturales mencionadas, en 1971, durante la gobernación de Héctor Polanía Sánchez, se fusionó la Promotora de Turismo y el Instituto de Cultura con el fin de crear el Instituto Huilense de Cultura y Turismo $(\mathrm{IHCT})^{55}$. Este esclarecido gobernador asignó al hombre de letras y pintor Benhur Sánchez como su director. Bajo esta administración en 1973 se estableció la necesidad de implementar la formación sistemática en los distintos lenguajes artísticos.

De esta manera, se fundó la primera "Escuela de Bellas Artes", mediante la Resolución 002 emanada del I.H.C. ${ }^{56}$. Las clases iniciaron el 12 de marzo de 1973, en la Calle $9^{a}$ Número 7 82 , con la participación de 50 estudiantes y los siguientes docentes para desarrollar los talleres de: "Cerámica Artística, Dibujo, Historia del Arte, Escultura y Pintura. Para Escultura ha sido nombrado el maestro Alejandro Valencia, para

\footnotetext{
${ }^{53}$ DIARIO DEL HUILA. Neiva, Martes 4 de Marzo de 1969.

${ }^{54}$ GACETA DEL HUILA. Año LXVII N ${ }^{\circ}$ 2381. Neiva, Ed. Imprenta Departamental, Diciembre 15 de 1968, pág. 5136.

${ }^{55}$ DIARIO DEL HUILA. Año V N ${ }^{\circ} 1801$. Sancionado Decreto que crea el nuevo Instituto Huilense de Cultura y Turismo. Neiva, viernes 6 de Abril de 1973, pág. 1 y 8 .

${ }^{56}$ DIARIO DEL HUILA. Año V N ${ }^{\circ}$ 1795. Con éxito inició labores la Escuela de Bellas Artes. Neiva, jueves 15 de Mayo de 1973, pág. 1 y 3.
} 
cerámica La prestigiosa ceramista Aura Gallardo y para Dibujo e Historia del Arte el director del Instituto Huilense de Cultura"57. En seguida, ingresó el maestro Phanor Satizabal para orientar los talleres de pintura.

La crisis de este proyecto formativo comienza con el cierre de la "Escuela de Cerámica" ${ }^{58}$ en agosto de 1974. Como razones del cese de actividades se argumentó: 1) la imposibilidad del I.H.C. para adquirir "elementos de dotación como un horno y un torno". 2) la falta de interés de la ciudadanía. 3) la "despreocupación de los alumnos". 4) la participación de solo 12 estudiantes, "número que se estima muy reducido para sostener un profesor en la materia". Con lo cual, "en la Escuela de Bellas Artes solo quedarán funcionando la enseñanza de pintura y las clases de danzas"59.

En 1975 ésta escuela fue fortalecida con la participación de los profesores Fito y Hollman, teniendo como "director, secretario y profesor" al arquitecto Guillermo Liévano Rodríguez, quien era además el "Jefe de Extensión Cultural de I.H.C". El grupo docente logró matricular 101 estudiantes para iniciar las actividades académicas de la Escuela de Bellas Artes. En este Programa "los cursos tienen una duración de cuatro años, siendo nocturnos con una intensidad de cinco días a la semana y tres horas diarias" ${ }^{60}$. Los cursos eran de "Pintura, dibujo, modelaje (sic) y cerámica... con un costo de $\$$ 200,00 , todo el año"61; como se observa, el pensum perdió la Historia del Arte, es decir, se orientaban los talleres sin la mínima orientación teórica.
Guillermo Liévano para convencer a la burocracia ayuna de educación artística y la ciudadanía insensible, respecto a las bondades del proyecto educativo, destaca lo siguiente: 1) Se habían inscrito 289 aspirantes, lo cual demuestra que "existe un elevado potencial artístico o de gentes con tendencias hacia estas manifestaciones del arte". 2) "Solamente 101 pasaron los exámenes de admisión...y entrevista personal". 3) "La escuela tendrá un alto nivel académico y universitario... porque estaremos asesorados por Antonio Madero, quien ha dirigido la Academia de Bellas Artes del Distrito Especial de Bogotá por espacio de 14 años". 4) "la escuela impartirá títulos universitarios que tendrán validez oficial por el Ministerio de Educación Nacional". 5) "Estos títulos serán expedidos por la Gobernación del Huila, la Secretaría de Educación y el Instituto Huilense de Cultura"62. En el listado de estudiantes admitidos se destacan los siguientes nombres por mantenerse hasta el presente activos: "Patricia del Socorro Tafur, Humberto Sánchez, Jairo Osorio, Emiro Garzón, Juan Rosillo,

No obstante, su funcionamiento no era el ideal si tenemos en cuenta que "la Escuela de Bellas Artes funciona en la misma casa de la biblioteca departamental, limitada por lo tanto en inapropiados y muy incómodos sitios. Cada noche iniciamos actividades acomodando en el garaje y los corredores las mesas destartaladas y los caballetes que al final de tanto trasteo quedarán igual que las mesas"63. Pese a toda la "mística que por las artes sienten los

\footnotetext{
${ }^{57}$ |bidem, pág. 3.

${ }^{58}$ DIARIO DEL HUILA. Año VIII N²119, Cierran Escuela de Cerámica. Neiva, domingo 4 de Agosto de 1974, pág. 2.

${ }^{59}$ Ibidem.

${ }^{60}$ DIARIO DEL HUILA. Año VIII Nº 2254. Con 101 alumnos comenzó la Escuela de Bellas Artes. Neiva, martes 25 de Febrero de 1975 , pág. 5. ${ }^{61}$ DIARIO DEL HUILA. Año VIII N²239, El Instituto Huilense de Cultura desde el lunes llama a clases. Neiva, viernes 7 de febrero de 1975, pág. 5.

¿2DLARIO DEL HUILA. Año VIII N²254. Con 101 alumnos comenzó la Escuela de Bellas Artes...Op. Ct.

${ }^{63}$ GAlVIS C., Ana Mercedes. Peñón Redondo, Centro Cultural en Diario del Huila. Año X N 2392 . Neiva, domingo 31 de Agosto de 1975 , pág. 5
} 
profesores, director y alumnos" ${ }^{44}$, debido a falta de espacios y recursos, aunado a inconvenientes políticos y presiones sociales, el cuerpo de profesores terminó renunciando en el año de 1975.

Al año siguiente la Escuela de Bellas Artes vuelve a iniciar labores, teniendo como directora a la ceramista Aura Gallardo de Segura. Al parecer también se produjo una desbandada de estudiantes, en razón a que la Directora de IHCT anunciaba que "la inscripción ha sido aceptable y que se tiene la certeza de que tan pronto entren en pleno funcionamiento todas las dependencias del Instituto se incremente el número de alumnos para cada escuela"65. En ese entonces funcionaban las Escuelas de Bellas Artes, Conservatorio, Teatro Experimental, Danzas clásicas y Folclóricas.

Esta vez el asesor sería José Enrique Viloria, Jefe de Pedagogia Artística de Colcultura; quien fue llamado para "asesorar la reorganización y puesta en marcha de todas las dependencias" del IHCT. Este funcionario realizó una serie de reuniones con los responsables de las distintas escuelas, anteriormente mencionadas, "con el fin de sentar las bases de coordinación y definir los programas que se aplicarán en adelante bajo la supervigilancia directa de Colcultura...con la visita del doctor Viloria se inicia el proceso de aprobación de la Escuela, de tal manera que se puedan expedir certificados debidamente reconocidos por el gobierno nacional, en circunstancial tales que los alumnos puedan vincularse a institutos de mayor capacidad académica y artística"66.
Al parecer, este etapa de la Escuela de Bellas Artes tampoco recibió el debido apoyo, si tenemos en cuenta el pronunciamiento del sacerdote Andrés Rosas en la inauguración de la exposición de trabajos, montada con motivo de clausura de semestre: "La directora de la Escuela doña Aurita quien al mismo tiempo es profesora de modelado, cocción y pintura de cerámica ha respondido presente. Su nombramiento ha rebasado los estrechos $y$ fríos límites de una nómina, de esas nóminas que con frecuencia son asilo de incompetencia e inacción. No. Ella no solo conoce su oficio sino que además, y esto es lo más importante, ofrece el fruto de su trabajo a través de la labor consagrada de sus alumnos, a pesar de que la Escuela trabaja con la uñas y alas de cucaracha"67. Con lo anterior, destacaba el orador tanto la eficaz labor de la directora, como la supuesta ineptitud de los directores anteriores y las pésimas condiciones de funcionamiento institucional.

Para 1976 la formación en la Escuela de Bellas Artes quedó reducida a "cursos de cerámica y pintura y cursos de pintura en cerámica"68 , como secuela de la grave crisis que afectaba a todo el IHCT, la obligada denuncia de la negligencia gubernamental ${ }^{69}$, la inmediata destitución de la Directora Cecilia Durán de Liévano, y el consecuente encargo del despacho a Pablo Emilio Gamboa Peña, mediante Decreto 0571 del 10 de Agosto del año en curso ${ }^{70}$. Mientras tanto, para atenuar la situación, el gobierno departamental había nombrado al artista Luis Chaux como profesor

\footnotetext{
${ }^{64}$ lbídem

${ }^{65}$ DIARIO DEL HUILA Año X N²533. El lunes inicia labores la Escuela de Bellas Artes. Neiva, sábado 23 de Febrero de 1976 , pág. 10. ${ }^{66}$ DIARIO DEL HUILA. Año X N²564. Alto funcionario de Colcultura asesora al Instituto del Huila. Neiva, miércoles 7 de Abril de 1976 , pág. 3 y 8

${ }^{67}$ DIARIO DEL HUILA. Año X N ${ }^{\circ}$ 2617. La Escuela de Bellas Artes. Neiva, martes 15 de Junio

${ }^{68}$ DIARIO DEL HUILA. Año X N²495. El 15 matriculas en Instituto de Cultura Neiva, miércoles 14 de Enero de 1976 , pág. 1 y 2

${ }^{69}$ DIARIO DEL HUILA. Año X N ${ }^{\circ} 2649$. Grave crisis en el Instituto de Cultura y Turismo. No hay con que pagar servicios. Suspendidos Conservatorio, Biblioteca y Escuela de Bellas Artes. Al Gobierno no le interesa la cultura. Deben 5 meses de arriendo! Neiva, jueves 5 de Agosto de 1976, pág. 1 y 3.

${ }^{70}$ DIARIO DEL HUILA. Año X N² 2653. Destituida Directora de Cultura y Turismo. Revuelo general por la medida del gobierno. Neiva, miércoles 11 de Agosto de 1976, pág. 1 y 3
} 
de Pintura e Historia del Arte en la Escuela de Bellas Artes ${ }^{71}$.

Por su parte, el economista Pablo E. Gamboa "introdujo algunas modificaciones en el funcionamiento del la Escuela de Bellas Artes y con el ánimo de incrementar el presupuesto asignado para el resto del presente año": 1) "eliminó la dirección. 2) "dejó a todo el profesorado laborando por horas tanto en pintura como dibujo y la historia del arte". 3) abrió "dos cursos de pintura en porcelana y cerámica". 4) cada curso con una duración trimestral y "tendrán un costo de doscientos pesos la matrícula, más los materiales que deben ser adquiridos por el personal interesado". 5) cada curso tendria "un cupo limitado de 15 personas y se desarrollará...de lunes a viernes, de seis a (sic) treinta a ocho y treinta de la noche, en las modernas instalaciones del bloque cultural de la Gobernación".6) para el curso de cerámica básica aplicada en el "desarrollo de las artes manuales. Se anota que en esta oportunidad los alumnos contarán con servicios de horno para la cocción de las piezas, aparato que estará instalado antes de ocho dias"72.7) los cursos estaban abiertos para distintas edades y niveles de educación.

Las reacciones no se dejaron esperar, sobre todo por la desaparición del cargo de la directora de la Escuela de Bellas Artes, que tuvo como efecto el pronunciamiento escrito del estamento estudiantil ante las directivas del
IHCT: "para solicitarle una pronta solución al problema, máxime cuando éste se agudiza en el sentido de que también se ha aumentado el horario de los instructores para así justificar la carencia de la dirección, hecho que no permite un normal desenvolvimiento académico. De otra parte los alumnos de la Escuela, manifestaron su extrañeza con la actitud asumida por el funcionario Rodrigo Rivera, quien en la noche de ayer manifestó que la Escuela sería clausurada y que quienes estaban recibiendo los estudios en el citado centro cultural, eran personas foráneas que no tenían derecho a recibir los beneficios del Instituto. Finalmente se ha manifestado...que los alumnos no estarán dispuestos a permitir el cierre de la Escuela de Bellas Artes cuando éste está prestando una eficiente labor a pesar de que el presupuesto de la escuela (no) es superior al millón de pesos, el cual fue gastado en las fiestas del festival del bambuco" 73 .

2.3 La Licenciatura de Artes Visuales de la Universidad Surcolombiana y "la educación visual no formal"

Seis años después, nacieron las Escuelas de Arte y sus respectivos Programas de Música, Danzas, Teatro y Artes Visuales, creados por el Gobierno Departamental mediante el Decreto $\mathrm{N}^{\circ} 0296$ de 1982. En este mismo año también se firmó el primer convenio con la Universidad Surcolombiana (USCO), para el diseño de los programas curriculares ${ }^{74}$. El convenio IHCUSCO fue modificado en 1987 y se unificaron

${ }^{71}$ DIARIO DEL HUILA. Año X No 2650. Luis Chaux profesor de pintura en Bellas Artes. Neiva, viernes 6 de Agosto de 1976 , pág. 1 y 5 ${ }^{72}$ DIARIO DEL HUILA. Año X N ${ }^{\circ} 2673$. Cursos de pintura en porcelana dictará Escuela de Bellas Artes. Neiva, viernes 3 de Septiembre de 1976 , pág. 1 y 8

${ }^{73}$ DIARIO DEL HUILA. Año X N² 2674. Crisis en la Escuela de Bellas Artes. Neiva, sábado 4 de Septiembre de 1976, pág. 1 y 8

${ }^{74} \mathrm{~A}$ través del Acta $\mathrm{N}^{\circ} 007$ y Acuerdo $\mathrm{N}^{\circ} 082$ del 9 Agosto de 1982, la USCO firmó un convenio con el IHC, con el fin de elaborar el estudio de factibilidad orientado a crear los Programas como modalidad de Licenciatura en Arte Escénico, Música y Artes Visuales, dependientes de la Facultad de Educación. Como efecto, se conformó un equipo integrado por profesores de la Facultad de Educación y las Escuelas de Arte quienes realizaron el proyecto para presentarlos ante el ICFES 
los tres programas conformando la llamada Escuela Superior de Artes del Huila ${ }^{75}$. En 1989 una comisión de verificación enviada por el Instituto Colombiano para el Fomento de la Educación Superior (ICFES), emitió el concepto favorable de los programas y otorgó la Licencia de Funcionamiento en diciembre del mismo año ${ }^{76}$ En febrero de 1990 la Universidad asignó al primer director de la Escuela Superior de Artes del Huila ${ }^{77}$.En 1994 la Universidad Surcolombiana asumió totalmente los tres programas de Licenciatura en Arte $^{78}$.

El programa de Licenciatura en Artes Visuales desde su puesta en funcionamiento hasta el año 2004 formó diez promociones ${ }^{79}$; cuyos profesionales han ocupado varias plazas en las instituciones educativas y culturales departamentales, sin llegar a la totalidad según lo analizado por lo Secretaría Departamental de Educación; otros trabajan en ONGs culturales. De manera similar los egresados han ocupado algunas plazas extradepartamentales; mientras un grupo pequeño, compuesto por unos siete egresados, se trasladó al exterior para realizar estudios de postgrado.

Tanto los estudiantes como los egresados han sido seleccionados en más del $50 \%$ de los eventos más significativos de la Región; uno de éstos eventos es el Salón Departamental de Artistas. En tales eventos artísticos los estudiantes y egresados han obtenido el reconocimiento correspondiente. Por ejemplo, en el IV Salón del año 2000 los egresados ganaron tres de las cinco Menciones de Honor y en el V Salón del 2001 obtuvieron dos de las tres Menciones; ya para el VI Salón Departamental del año 2002 un estudiante de VIII semestre obtuvo el Primer Premio Bidimensional, mientras a un egresado le otorgaron una de las tres Menciones de Honor. Posteriormente el mismo premio fue asignado a una egresada en el VII Salón del año 2003. No obstante, no se ha logrado formar los artistas visuales que representen al Huila en el ámbito nacional e incidan de manera contundente en la cualificación de las obras emplazadas en el espacio público.

Se debe puntualizar que el objetivo general de una Licenciatura en Artes Visuales dentro de una Facultad de Educación, se encamina a formar docentes para que orienten procesos en el Área de Educación Artística en los distintos niveles de la Educación Básica y Media; mientras el dominio técnico, la articulación de los referentes conceptuales y el desarrollo de la creatividad,

\footnotetext{
${ }^{75}$ El 5 de mayo de 1987 se modificó el convenio para el desarrollo de los programas académicos, comprometiéndose el IHC a designar los docentes de las Escuelas de Artes para laborar junto a los docentes de la Facultad de Educación. El IHC dispuso los espacios físicos, los recursos y el presupuesto para el funcionamiento de los programas. Por su parte, la USCO se comprometió a asignar un docente con el cargo de Director Académica, con participación en el Consejo Académico, para orientar los procesos formativos. La ratificación del convenio implicó formar diez (10) promociones en cada uno de los programas. Este convenio fue autorizado por medio del Decreto presidencial $\mathrm{N}^{\circ} 2363$ del 14 de diciembre de 1987.

${ }^{76}$ EI conjunto de docentes de la USCO y de la Escuela de Artes, con la asesoria del ICFES, consolidaron los programas académicos; los cuales fueron aprobados por el Consejo Superior de la Universidad mediante Acuerdo 0012 del 25 de febrero de 1988. A continuación, el ICFES otorgó la licencia de funcionamiento para los 3 programas mediante el Acuerdo $N^{\circ} 150$ de noviembre de 1989 . Las actividades académicas iniciaron en $2^{\circ}$ periodo de 1989 . Tres años más tarde, el ICFES mediante Resolución $N^{\circ} 00373$ del 28 de febrero de 1992 , aprobó los programas mencionados.

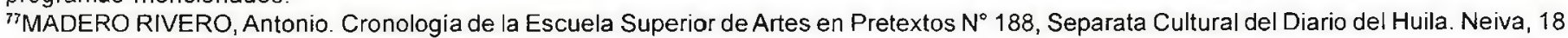
de febrero de 1990, pág. 8.

${ }^{78}$ En 1993 el IHC sufrió una drástica restructuración. Como efecto, varios docentes de los Programas de Artes fueron despedidos, mientras otros se asimilaron con el cargo de "promotor cultural". Lo anterior significó la inserción de los Programas de Arte en la USCO, a través de un nuevo convenio; en este documento el Departamento del Huila se comprometió a girar anualmente los recursos destinados al pago de la adecuación de espacios, la nómina docente y la compra de recursos didácticos; por su parte, la Universidad suministraba las aulas y la organización académica. Cuando en el periodo siguiente, el Gobernador de turno, no cumplió con los aportes económicos a la USCO aduciendo iliquidez y crisis fiscal. Entonces, la Universidad desde el año 1994 asumió toda la responsabilidad para el desarrollo académico de las tres licenciaturas.

${ }^{79}$ No sobra advertir que desde el año 2001 la Universidad Surcolombiana ha dejado de admitir nuevas cohortes para el Programa de Licenciatura en Artes Visuales, debido a las altas exigencias que ahora requieren los procesos de acreditación.
} 
inmanentes de la concreción de un lenguaje de expresión propio, corresponde más a una Maestría que se desarrolla en una Facultad de Artes.

Sin embargo, y pese a limitantes como la carencia de espacios, recursos y docentes, el Programa de Artes Visuales de la Universidad Surcolombiana se preocupó por ofrecer a sus estudiantes los elementos teóricos y prácticos que le permiten a sus egresados desempeñarse tanto en el ámbito educativo como en el creativo. Con ello, se ha avanzado más en el desarrollo de las capacidades creadoras de lo que comúnmente se espera con un programa de esta categoría. Su impacto más notorio se evidencia en la dinamización de las instituciones y los procesos artísticos del Departamento.

Con la intención de ofrecer una formación más cualificada, durante el primer semestre del año 2002 el Departamento de Artes presentó y sustentó el proyecto de creación de la Facultad de Artes de la Universidad Surcolombiana, el cual fue aprobado por las distintas instancias; luego se produjo su retroceso durante la administración del abogado Eduardo Beltrán. Ahora sólo falta voluntad política, la sensibilidad estética y la decisión académica inteligente de quien resulte ser un próximo rector, seriamente comprometido con el desarrollo artístico y cultural del Departamento del Huila; o en su defecto, para ponerla en marcha en cualquier Universidad que haga presencia en el Departamento.

En cuanto a la formación artística no formal la Escuela de Formación Artística del Alto Magdalena (ESAM) la cual inició labores académicas en 1993 direccionada por la División Escuelas de Artes del Instituto Huilense de Cultura, como una alternativa sólida de formación en los municipios de Neiva, Garzón, Pitalito y la Plata ${ }^{80}$ sucumbió con los cambios de orientación cultural de los gobiernos departamental y municipales, además de la miopía de quienes eran encargados de impulsar el desarrollo educativo y cultural a nivel departamental.

Hasta el año 2004 se implementó una segunda fase de la ESAM desde la Secretaría de Cultura con una orientación no dirigida a la creación y producción artística, sino a la Educación por el Arte con el fin de constituirse en un aporte ante los problemas sociales, postura que tiene toda validez. Hoy, en un tercer momento, el Fondo Mixto de Cultura se ha encargado de su desarrollo.

También son loables los esfuerzos llevados a cabo por algunos docentes, ONGs culturales y asociaciones que con esfuerzo se preocupan por ofrecer cursos libres a diferentes poblaciones; aunque algunas de ellas carecen de las orientaciones que ofrecen las teorías y los teóricos de la educación artística y del desarrollo humano, para terminar tan solo en una simple habilitación en la producción manual sin la articulación de los referentes conceptuales obligatorios del arte actual. Dentro de los talleres que funcionan en Neiva, orientados a "la educación visual no formal", se señalan como los de mayor importancia: el "Círculo Cromático" del profesor Arturo Ignacio Flórez y "El Taller" de la pintora Margarita Rosa Gómez.

Respecto a la educación visual informal cada vez se fueron ampliando los espacios en revistas, periódicos, prensa y televisión local y nacional; no obstante, las programaciones y eventos reseñados no obedecen a planeaciones para lograr impactar de manera significativa a las comunidades, teniendo en cuenta las orientaciones dadas por el Ministerio de Cultura en el sentido de "desarrollar procesos interinstitucionales" que culminen en "eventos", con el fin de superar el "activismo artístico", que es lo prevaleciente.

${ }^{80}$ CABRERA, Leo. La ESAM: Alternativa Pedagógica en Culturaria Separata Dominical No 44 del Diario del Huila. Neiva, domingo 4 de abril de 1993, pág. 3. 